\title{
Metabolic parameters and gut microbiota composition of rats fed high-fat diets based on ruminant fat compared with hydrogenated vegetable fat
}

\section{Larissa Brito Medeiros}

Federal University of Paraíba

Susana Paula Almeida Alves

University of Lisbon

Rui José Branquinho Bessa

University of Lisbon

Juliana Késsia Barbosa Soares

Federal University of Campina Grande

Camila Neves Meireles Costa

Federal University of Paraíba

Jailane Souza Aquino

Federal University of Paraíba

Gerlane Coelho Bernardo Guerra

Federal University of Rio Grande do Norte

Daline Fernandes Souza Araújo

Federal University of Rio Grande do Norte

Lydiane Tavares Toscano

Federal University of Paraíba

Alexandre Sérgio Silva

Federal University of Paraíba

Adriano Francisco Alves

Federal University of Paraíba

Mateus Lacerda

Federal University of Paraíba

Wydemberg José Araujo

Federal University of Paraíba

Ariosvaldo Nunes Medeiros

Federal University of Paraíba

Celso José Bruno Oliveira

Federal University of Paraíba

Rita Queiroga ( $\nabla$ rcqueiroga@uol.com.br) 
Federal University of Paraíba

\section{Research Article}

Keywords: Trans-fatty acids, Conjugated linoleic acid, Hydrogenated Vegetable Fat, Inflammation, Cardiovascular disease,

Posted Date: March 4th, 2021

DOI: https://doi.org/10.21203/rs.3.rs-267429/v1

License: (c) (1) This work is licensed under a Creative Commons Attribution 4.0 International License. Read Full License 


\section{Abstract}

This study tested the hypothesis that naturally and industrially produced trans fatty acids (TFA) exert distinct effects on rats' metabolic parameters. Wistar rat groups were fed the diets: CONT - without added fat; HVF $20 \%$ hydrogenated vegetable fat (HVF); and RUM $-20 \%$ ruminant fat. Biochemical markers, cytokine levels, fatty acid (FA) composition of liver, heart and adipose tissue, liver histology and the gut microbial composition were also evaluated. Rats fed RUM presented lower deposition of adipose tissue and LDL and higher HDL and anti-inflammatory IL-10 than those fed CONT and HVF. Pro-inflammatory cytokines, malondialdehyde (MDA) and aspartate aminotransferase (AST) were higher in group HVF than CONT and RUM. In all types of tissue, the highest TFA levels were observed in rats fed HVF, which contributed to the development of fatty liver. The RUM diet led to higher concentrations of stearic acid and conjugated linoleic acid (CLA). The lower incorporation of TFA and distinct FA profile in the liver of rats fed RUM compared to HVF could be associated with protection hepatic. The microbial gut communities were significantly dissimilar among the groups. It is plausible that ruminant fat might reduce risk parameters involved in the development of cardiovascular disease.

\section{Introduction}

In recent decades, with the food industries' globalisation, there has been an increase in the availability of processed food products containing high amounts of hydrogenated vegetable fat (HVF), rich in industriallyproduced trans-fatty acids (iTFA) ${ }^{1}$. The negative effects on human health associated with iTFAs ingestion have been demonstrated since the 1990s by studies on cardiovascular risk indicators, such as increased LDL cholesterol, reduced HDL cholesterol, compromised endothelial function, and increased inflammation ${ }^{2-4}$.

Trans fatty acids are defined as unsaturated fatty acids with at least one unconjugated double bond with trans configuration ${ }^{5}$. In addition to being present in large quantities in processed products containing HVF, they are also found naturally in small quantities in meat, milk and their derivatives ${ }^{6-9}$.

In recent years, there has been increased consumer interest in the fatty acid (FA) composition of ruminant products such as milk and meat due to their saturated FA (SFA) content ${ }^{10}$. SFA have been implicated in diseases associated with modern life, such as the risk of developing atherosclerosis and other cardiovascular diseases ${ }^{2,3}$. Milk and dairy products are major sources of myristic acid (14:0) in human food, and ruminant foods contribute significantly to the consumption of palmitic acid (16:0) and TFA ${ }^{11}$.

Ruminant TFA (rTFA) are produced by the enzymes of microorganisms present in animals' rumen through biohydrogenation, which is a complex process resulting in isomerisation, hydration or hydrogenation of unesterified unsaturated dietary $F A^{6}$. After being produced, rTFA are absorbed and incorporated in body tissue and milk lipids ${ }^{6,7}$. Therefore, meat and milk from ruminants are the primary natural sources of TFA ${ }^{8}$.

Biohydrogenation produces various trans and cis isomeric FA, with trans-octadecenoates being quantitatively the most important group. Among the trans-octadecenoates from ruminant products, the vaccenic acid (18:1 $t 11)$ is usually the most abundant ${ }^{9}$. Conjugated linoleic acids (CLA), a group of geometric and positional conjugated isomers of linoleic acid, are also found in significant concentrations in ruminant animals' milk 
and meat. Of the CLA, rumenic acid $(18: 2 c 9, t 11)$, mostly derived from endogenous desaturation of $18: 1 t 11$, is the most commonly found CLA in ruminants ${ }^{7}$.

Fats from industrial and natural sources contain the same trans-octadecenoates, but in different proportions. Elaidic acid (18:1 t9) is the major isomer generated during industrial hydrogenation of oils, and the 18:1 t6, $18: 1 t 7,18: 1 t 8$ and $18: 1 t 10$ isomers are also predominant. This isomeric profile contrasts with that of rTFA, where often the 18:1t11 is the overwhelming trans-octadecenoate isomer ${ }^{12}$. Thus, dietary fats may have distinct metabolic effects, according to the predominant FA types ${ }^{13}$.

HVF has been consistently associated with increased risk markers for cardiovascular disease ${ }^{14}$, while the impact of total ruminant fat intake and rTFA on the development of human chronic diseases is unclear ${ }^{7}$. The lack of effect of rTFA may be due to relatively low levels of intake or may be related to the endogenous conversion of $18: 1 t 11$ to $18: 2 \mathrm{c} 9 t 11$, which may have health benefits ${ }^{15}$.

TFA intake has been associated worldwide with increased risks of developing cardiovascular disease. Health agencies from different countries and the World Health Organization (WHO), have joined forces to reduce TFA content in food and thus reduce its consumption by the population ${ }^{8,16,17}$. In Brazil, regulatory actions prepared by the National Health Surveillance Agency (ANVISA) have resulted in a mandatory declaration of TFA content in to be placed on the labels on packaged foods, but the definition of trans fat comprises both iTFA and TFA $^{18}$. Thus, dietary recommendations on TFAs do not differentiate between the sources of these compounds.

Moreover, the gut microbiota is affected mainly by diet, and dietary fat can alter the proportions of microorganisms responsible for some endogenous host responses such as inflammation, hormonal shifts and digestion ${ }^{19}$. For instance, high-fat diets (HFD) have been shown to influence diet-host interactions and predispose obesity and related disorders in mice ${ }^{20,21}$. However, there is still a lack of information on how fat sources could shape the gut microbioma. As changes in dietary FA composition can significantly affect several critical physiological processes, ${ }^{22,23}$ the present study aimed to test the hypothesis that naturally and industrially produced TFAs exert distinct effects on rats' metabolic parameters and microbiota.

\section{Materials And Methods}

\section{Body weight and feed intake}

Animals were weighed weekly using a digital electronic scale (Toledo, prix III, São Bernardo do Campo, Brazil). Feed intake was evaluated three times per week and expressed as the difference between offered feed and residual feed. The feed conversion rate was computed dividing the feed intake by the weight gain in a given period.

\section{Euthanasia and tissue preparation for analysis}

The animals were euthanised at 113 days of age, after being fed the experimental diet for 52 days. The animals had been fasted for $12 \mathrm{~h}$ and then weighed and anaesthetised with ketamine hydrochloride and 
xylazine hydrochloride administered via intraperitoneal. The rats were then euthanised by section of the aorta arteries. Whole organs and tissues (heart, liver and adipose tissue) were removed, cleaned and weighed on an analytical balance. The organs and tissues of six animals from each group were kept at $-80^{\circ} \mathrm{C}$ until oxidative stress, lipid profile and fatty acid analyses could be performed. The organs and tissues of the remaining three animals per group were washed in saline solution $(0.9 \% \mathrm{NaCl})$ and fixed in $10 \%$ buffered formalin until histological analysis could be carried out.

\section{Blood serum biochemical parameters}

Blood samples, after euthanasia, were centrifuged (58 $136 \mathrm{~g}$ for $15 \mathrm{~min}$ at $25^{\circ} \mathrm{C}$ ) to obtain serum samples that were kept at $-80^{\circ} \mathrm{C}$ until biochemical analyses were performed. Total cholesterol and fraction of high density (HDL), low density ( $L D L)$ and very low density lipoproteins (VLDL), triglycerides, glucose, alanine aminotransferase (ALT) and aspartate aminotransferase (AST) were quantified by commercial kits (Labtest, Minas Gerais, Brazil), according to manufacturer's guidelines, using an automatic biochemical analyser LabMax 240 (Minas Gerais, Brazil).

\section{Serum cytokine levels}

The serum cytokine levels were evaluated using the protocols of the kits (R\&D Systems, Minneapolis, MN), using standard capture and detection antibodies for IL-1 $\beta$, TNF-a, and IL-10. The serum samples were homogenised with phosphate buffer $(10 \mathrm{mM}, \mathrm{pH} 7.2-7.4)$, and centrifuged at $4000 \mathrm{~g}$ at $4{ }^{\circ} \mathrm{C}$ for $10 \mathrm{~min}$ so that the supernatant from the centrifugation could be used to determine the cytokines at an absorbance of $450 \mathrm{~nm}$ in an ELISA reader.

\section{Fatty acid}

Heart, liver and adipose tissue samples were freeze-dried and sent to the Faculty of Veterinary Medicine at the University of Lisbon for FA analyses. Fatty acid methyl esters (FAME) and dimethyl acetal (DMA) from the tissue samples were prepared by reaction with $\mathrm{HCl} 1.25 \mathrm{M}$ in methanol for $20 \mathrm{~h}$ at 50 ॰C. They were then analysed by gas chromatography with flame ionisation detection using a Shimadzu GC 2010-Plus (Shimadzu, Kyoto, Japan) equipped with a SP-2560 (100 m × $0.25 \mathrm{~mm}, 0.20 \mu \mathrm{m}$ film thickness, Supelco, Bellefonte, PA, United States) capillary column. The chromatographic conditions were as follows: injector and detector temperatures were set at 250 and $280^{\circ} \mathrm{C}$, respectively; helium was used as the carrier gas at 1 $\mathrm{mL} / \mathrm{min}$ constant flow; the initial oven temperature of $50{ }^{\circ} \mathrm{C}$ was held for $1 \mathrm{~min}$, increased by $50{ }^{\circ} \mathrm{C} / \mathrm{min}$ to $150{ }^{\circ} \mathrm{C}$ and held for $20 \mathrm{~min}$; then increased by $1^{\circ} \mathrm{C} / \mathrm{min}$ to $190^{\circ} \mathrm{C}$; and finally increased by $2{ }^{\circ} \mathrm{C} / \mathrm{min}$ to $220^{\circ} \mathrm{C}$ and held for $40 \mathrm{~min}$. Identification of FAME and DMA were achieved by comparison with commercial standards (FAME mix 37 components, Supelco Inc, Bellefont, PA, USA), by comparison with published chromatograms ${ }^{24}$ and by using electron impact mass spectrometry using a Shimadzu GC-MS QP2010 Plus (Shimadzu). The chromatographic column and the GC conditions used in the GC-MS were similar to the GCFID analyses. Additional mass spectrometer conditions were as follows: ion source temperature, $200{ }^{\circ} \mathrm{C}$; interface temperature, $240^{\circ} \mathrm{C}$; and emission voltage, $70 \mathrm{eV}$.

\section{Assessment of Lipidic Peroxidation Levels}


Lipid peroxidation was measured by the chromogenic product of 2-thiobarbituric acid (TBA) reaction with malondialdehyde (MDA), a product formed as a result of membrane lipid peroxidation ${ }^{25}$. The livers were homogenised with $\mathrm{KCl}(1: 1)$, and samples of tissue homogenate $(250 \mu \mathrm{L})$ were incubated at $37^{\circ} \mathrm{C}$ for 60 min. After that, the mixture was precipitated with $35 \%$ perchloric acid and centrifuged at $1207 \mathrm{~g}$ for 20 min at $4{ }^{\circ} \mathrm{C}$. Then, the supernatant was collected and $400 \mu \mathrm{L}$ of $0.6 \%$ TBA was added and incubated at $95-100{ }^{\circ} \mathrm{C}$ for $1 \mathrm{~h}$. After cooling, the samples were read in a spectrophotometer at a wavelength of $532 \mathrm{~nm}$ (Biospectro, SP-220 model-Brazil). MDA concentration was determined by substituting the absorbance values in the MDA standard curve obtained on the basis of a standard solution $(1 \mu \mathrm{L}$ of 1,1,3,3-tetramethoxypropane in $70 \mathrm{~mL}$ distilled water) diluted in series of $250,500,750,1000,1250,1500,1750,2000,2250,2500,2750$, and 3000 $\mu \mathrm{L}$ of distilled water.

\section{Antioxidant Activity}

The liver homogenate was assembled as previously described. In addition, an aliquot of $1.25 \mathrm{mg}$ of DPPH was diluted in ethanol $(100 \mathrm{~mL})$, kept under refrigeration, and protected from light. Then, $3.9 \mathrm{~mL}$ of DPPH solution was mixed with $100 \mu \mathrm{L}$ of the supernatant liver homogenate in appropriate centrifuge tubes. These tubes were vortexed and left to stand for $30 \mathrm{~min}$, then centrifuged at $1207 \mathrm{~g}$ for $15 \mathrm{~min}$ at $20^{\circ} \mathrm{C}$. Then, the samples were read in a spectrophotometer at a wavelength of $515 \mathrm{~nm}$ (Biospectro, SP-220 model-Brazil) ${ }^{26}$. Results were expressed as the percentage of the oxidation inhibition: $A O A=100-(((D P P H \cdot R) S /(D P P H \cdot R)$ B) $\times 100)$, where $(D P P H \cdot R) S$ and $(D P P H \cdot R) B$ corresponding to the concentration of DPPH. remaining after $30 \mathrm{~min}$, measured in the sample (S) and blank (B) prepared with distilled water.

\section{Histological evaluation of liver}

The liver was removed from the rats, washed in saline solution $(0 \cdot 9 \% \mathrm{NaCl})$ and fixed in $10 \%$ buffered formalin. The major lobe was subjected to a histological procedure according to the routine technique at the Pathology Laboratory (Department of Physiology and Pathology/CCS/UFPB) for obtaining blocks from which semi-serial 4- $\mu \mathrm{m}$ sections were cut. The slides were hydrated, stained with haematoxylin-eosin (HE), dehydrated, diaphanised in xylol and mounted with Entellan ${ }^{\circledR}$ for optical microscopic analysis (Motic BA 200, Olympus Optical Co, Philippines). Inflammatory exudate, hyperaemia, haemorrhage, necrosis, preservation of the hepatic parenchyma (cell integrity, centralised nuclei and highly evident nucleoli) and degenerative processes (e.g. fat degeneration) were evaluated in these liver histological sections ${ }^{27}$.

For morphometric analysis, twenty random images from slides of liver tissue were used. Under an Axiolab light microscope (Zeiss) with $400 \times$ resolution, twenty images were relayed to an image analysis system (Kontron Elektronik image analyser; Carl Zeiss, Germany-KS300 software). Reading of slides was performed randomly by two pathologists. A $10 \times$ objective and $40 \times$ photomicrograph of liver were used to obtain the images.

\section{Gut microbiota composition by high-throughput $16 \mathrm{~S}$ rRNA sequencing}

Stool samples from animals were collected at three consecutive days just before euthanasia. Genomic DNA was extracted from stool using a commercial kit (PowerSoil DNA, Qiagen, Germany). DNA integrity was assessed using a $1 \%$ agarose gel and quantified by fluorometry (Qubit, LifeTechnologies, USA). Amplicon 
libraries were prepared for the V3-V4 regions using Nextera XT Indexkit (Illumina) amd magnetic beadsfor cleaning and purification (AMPureXP, Beckman, Indianapolis, USA). Paired-end sequencing was performed in Illumina MiSeq using a 500 cycle $(2 \times 250)$ V2 kit.

The raw demultiplexed paired-end sequences were downstream processed in QIIME 2 platform v.20.8 28 . Reads were filtered, denoised and parsed for non-chimeric sequences using DADA2 ${ }^{29}$, producing Amplicon Sequence Variants (ASV) and it respective feature table. For phylogeny, sequences were aligned using SEPP ${ }^{30}$ according to Green Genes v.13.8 reference sequences. Apha diversity was evaluated by Chao1, Simpson and Shannon indices, while beta diversity was analysed by means of both weighted and unweighted Unifrac distance matrices. The visualisation plots of relative abundances, alpha and beta diversity metric measures were performed using phyloseq v.1.8.2 $2^{31}$ in R v.3.5.7. Taxonomic classifications were attributed using the Naïve Bayes method based on Green Genes database v. 13.8 with $99 \%$ of similarity for the V3-V4 regions ${ }^{32}$. Differential abundance was assessed using machine learning classification of ASV based on the Random Forest method using nested stratified $k$-fold cross validation for automated hyperparameter optimisation and sample prediction, then taxonomic classification was performed using BLASTn ${ }^{33}$ based on each amplicon sequence.

\section{Statistical analysis}

The data were analysed using the SAS software (SAS inst., Cary) to apply a linear model where the dietary treatment was the single fixed factor and the animals as the experimental units. Whenever significant effects were detected $(p<0.05)$ the least square means were compared by the Tukey post hoc multiple comparison test. The non-parametric tests Kruskal-Wallis and PERMANOVA were used to assess the statistical significance of alpha and beta diversity, respectively. Machine learning based on the fandom forest method was used to perform microbial differential abundances.

\section{Results}

\section{Body and tissues weights and feed intake}

The feed intake was higher $(p<0.001)$ for CONT than for the fat diets (HVF and RUM) which were the same (Table 2). The body weight gain did not differ among treatments (Table 2). Feed conversion rate was higher $(p<0.001)$ for RUM and HVF than for CONT (Table 2). The weight of the hearts and livers did not differ among treatments. The RUM presented lower accumulation of adipose tissue $(p<0.05)$ than the HVF and CONT groups (Table 2).

\section{Blood serum biochemical parameters}

There were no significant differences regarding glucose, triglycerides, total cholesterol, VLDL and ALT serum parameters among the dietary treatments. However, RUM presented higher serum HDL and lower serum LDL than CONT and HVF $(p<0.05)$, while HVF diet increased the level of AST serum compared to CONT $(p<0.05)$, but not to RUM (Table 3).

\section{Serum cytokine levels}


When determining serum cytokine levels, it was observed that HVF presented larger amounts of IL-1 3 ( $277 \pm$ $63.2 \mathrm{pg} / \mathrm{mL})$ compared to CONT $(201 \pm 24.4 \mathrm{pg} / \mathrm{mL})(p<0.05)$ and higher TNF-a content $(647 \pm 25.4 \mathrm{pg} / \mathrm{mL})$ compared to CONT $(570 \pm 21.1 \mathrm{pg} / \mathrm{mL})$ and RUM $(561 \pm 16.2 \mathrm{pg} / \mathrm{mL})(p<0.001)$. When the IL-10 concentration was evaluated, RUM presented a higher concentration $(794 \pm 49.4 \mathrm{pg} / \mathrm{mL})$ when compared to CONT $(671 \pm 47.9 \mathrm{pg} / \mathrm{mL})$ and HVF $(690 \pm 93.1 \mathrm{pg} / \mathrm{mL})(p<0.05)($ Fig.1).

\section{Fatty acid}

The detailed FA composition ( $\mathrm{mg} / \mathrm{g}$ dry tissue) of the liver, adipose tissues and heart of rats are presented in Tables 4, 5 and 6, respectively. As expected, the diets had a profound effect on FA composition in all tissues studied. Some groups of FA showed a similar pattern of response to treatments across tissues. Thus, in all tissues, the trans-octadecenoates, other than 18:1t11, were highest $(p<0.05)$ for HVF treatment than the for other treatments, and the tissues from RUM and CONT treatments did not differ significantly. The 18:1t11 was similar in HVF and RUM treatments and lower in the CONT. Tissues from rats from HVF treatment also presented higher concentration of some cis-octadecenoic isomer like 18:1c12 and 18:1c13 as well as the sum of 18:2 isomers (18:2oi, most of them with at least one trans double bond). In all tissues, the RUM treatment resulted in the highest concentration of 18:0, 18:2c9t11 (CLA), and most of the branched-chain FA (BCFA), different from the other treatments. The $18: 1 \mathrm{c} 9$ was also highest with RUM than with the other treatments in heart and adipose tissue but not in the liver.

In the liver, and excluding the 18:0, all the other main FA (i.e. 16:0, 18:1c9, 18:2n-6, 20:4n-6, and 22:6n-3) did not differ among treatments. In the adipose tissue, the HVF group presented the lowest concentration of 16:0, and of total SFA, whereas both HVF and RUM presented lower concentrations of most PUFA, including 18:2n$6,20: 4 \mathrm{n}-6,20: 5 \mathrm{n}-3$ and $22: 6 \mathrm{n}-3$ than CONT. The concentration of total FA in the liver averaged $101 \pm 11.1 \mathrm{mg} / \mathrm{g}$ dry tissue and did not differ among treatments.

In the heart, the RUM treatment resulted in a general larger $(p<0.001)$ deposition of FA than in the other treatments; these were similar $(131 \pm 6.7,99 \pm 7.9$ and $83 \pm 6.7 \mathrm{mg} / \mathrm{g}$ dry tissue, respectively for RUM, HVF and CONT). As a consequence, RUM treatment presented the highest concentration of SFA and cis-MUFA, although similar n-6 PUFA, compared to the other treatments. The content of n-3 PUFA was higher in both HVF and RUM and lower in CONT.

\section{Assessment of lipidic peroxidation levels and antioxidant activity assay}

The MDA content present in the HVF rat livers was higher $(0.8 \pm 0.03 \mu \mathrm{mol} / \mathrm{g})$ than CONT $(0.24 \pm 0.02$ $\mu \mathrm{mol} / \mathrm{g})$ and RUM $(0.20 \pm 0.03 \mu \mathrm{mol} / \mathrm{g})(p<0.001)$, while the antioxidant activity did not differ among treatments (Fig. 2).

\section{Histological evaluation of liver}

The rats fed HVF diet had livers with macroscopic lesions compatible with fatty liver syndrome (Fig. 3(A)), which was confirmed by the higher histological morphometry of the hepatic steatosis compared to CONT and RUM (Fig. 3(B)) $(p<0.001)$. There was no change in the hepatic parenchyma of the CONT animals. However, 
the livers of rats fed RUM diet, despite not having a fatty liver, showed milder inflammation in the histological evaluation.

\section{Gut microbiota composition}

No significant differences were observed between treatments regarding richness and evenness of the gut microbial communities as evidenced by the alpha diversity indices Chao1, Shannon and Simpson (Supplementary Fig.1, 2 and 3). Nevertheless, the microbial gut communities differed $(p<0.048)$ in their beta diversity, particularly that of RUM treatment (Fig. 4). Relative abundances of the most abundant phyla (Firmicutes, Bacteroidetes and Proteobacteria) and genera (Anaerorhabdus, Clostridium, Eubacterium, Helicobacter, Prevotella, Ruminococcus, Selenomonas) across the treatments are shown in Supplementary material figures (Supplementary Fig. 4, 5 and 6).

The differential abundance analysis revealed increased abundance of Lachnispiraceae, Pseudoflavonifractor and Blautia in the gut of rats receiving RUM diet. Ruminoccocus abundance seemed not to be affected by diets. Prevotella and Monoglobus were reduced in the gut of animals receiving both HVF and RUM (Fig. 5).

\section{Discussion}

Cardiovascular disease (CVD) is the leading global cause of death in Western countries, and its development is associated with unhealthy dietary patterns ${ }^{34}$. Therefore, evaluating the influence of different types of HFD on metabolic aspects related to cardiovascular health is crucial because the harmful effects of the HFD could differ with the type of fat included in the diet ${ }^{35}$.

As expected, the feed intake was lower with HFD diets than CONT, which can be explained by the higher energy density of the HFD diets and the fat-induced satiety regulatory mechanisms ${ }^{36}$. As animals reduced the intake of HFD, there was also no effects on body weight gain, suggesting that energy intake remained similar among treatments.

Despite this, rats fed RUM presented a lower accumulation of abdominal and epididymal adipose tissue than HVF and CONT groups. It is tempting to attribute this decrease in adipose tissue weight to the effects of stearic acid (18:0) present abundantly in ruminant fat. In fact, Shen and colleagues ${ }^{37}$ demonstrated that dietary stearic acid leads to reduced abdominal fat through injury and cell death via apoptosis in preadipocytes. It did not form part of the present study to record the weight of gastrointestinal content and tissue and the carcass, and thus it is not possible to know which body component was increased to compensate for the adipose tissue decrease and still maintain the same BW.

Rats fed with RUM diet had favourable changes in their serum lipoprotein profile compared to HVF and CONT diets, due to the higher HDL levels and lower LDL levels, while serum cholesterol total and triacylglycerol concentrations were not modified. This favourable effect of RUM on blood lipoproteins compared to CONT is surprising as the HFD diet is rich in SFA including the hypercholesterolaemic 14:0 and 16:0; ${ }^{38}$ but the effect may have been associated with the reduced adipose tissue mass. Some studies have reported that feeding commercial CLA mixtures, ${ }^{39}$ or 18:2c9t11 CLA ${ }^{40,41}$ raised the animals' serum HDL levels. Further, it has been 
reported that CLA feeding can decrease serum LDL levels in rats ${ }^{42}$. Thus, CLA supplied in the RUM diet could contribute to the favourable lipoprotein response, although the diet's CLA concentration was much lower than that in the dietary CLA supplementation experiments.

The increased HDL level is potentially a beneficial result because it is well known that increased HDL blood levels are atheroprotective ${ }^{43}$, while increased LDL in blood is associated with increased risk of atherosclerotic $\mathrm{CVD}^{44}$. As it is well established that TFA increases LDL and decreases HDL cholesterol ${ }^{45}$, it is surprising that the rats fed HVF diet did not display this type of response.

Consistently, with lower adipose tissue mass and improved blood lipoprotein concentration, the rats fed RUM diet also had higher anti-inflammatory cytokine IL10, whereas the HVF group presented elevated concentrations of pro-inflammatory cytokines. In vitro studies have demonstrated an anti-inflammatory effect of ruminant fat that may somehow contribute to explaining our results. Some rTFA may decrease the production of inflammatory prostaglandins and down-regulate the TNF gene expression in endothelial cells ${ }^{46}$ and CLA by increased adiponectin secretion anti-inflammatory marker ${ }^{47}$.

The high intake of TFA in rats fed HVF diet was reflected in the increased TFA deposition in the tissues as also reported by Dhibi et al., ${ }^{48}$ and in the occurrence of histological atherosclerotic lesions. In this context, HVF diet caused an increase of pro-inflammatory serum cytokines IL-1 $\beta$ and TNF-a cytokines. A plethora of data has demonstrated the role of IL-1 $\beta$ and TNF-a cytokines in atherosclerosis and CVD ${ }^{49-51}$ and that its concentrations in the blood are elevated in chronic heart failure patients ${ }^{49}$.

Thus, the HVF diet in the present study increased the risk of CVD by raising levels of pro-inflammatory cytokines, although it did not change the serum lipoprotein cholesterol markers. Dietary intake of TFA is translated directly into an increased TFA concentration in the various tissues, as we demonstrated above for in the liver, heart and adipose tissue. Elevated TFA concentrations have been associated with systemic and local inflammatory responses ${ }^{52}$.

In fact, in addition to dietary concerns, TFA increases serum levels of TNF-a in mice ${ }^{53}$, Mozaffarian and others ${ }^{54}$ have demonstrated that TFA is associated with the activation of systemic inflammatory responses, including substantially increased levels of IL-6, TNF-a and TNF receptors in patients with established heart failure. This association between TFA and inflammatory mediators has been confirmed by in vitro studies that demonstrated that peritoneal macrophages from rats fed HVF secreted more pro-inflammatory cytokines like TNF-a and IL-6 than macrophages from rats fed n-6 and n-3 PUFA-rich diets ${ }^{55}$.

Monguchi et al. ${ }^{52}$ demonstrated that in LDL receptor-deficient mice, in addition to inducing an increase in inflammatory cytokines, such as TNF-a and IL-1 $\beta$, the LDL also induced oxidative stress. Similarly, in the present study, we demonstrated that HVF diet increased lipid peroxidation in the liver, as evaluated by the higher MDA content liver of HVF fed rats. Elevated concentration of MDA in the liver is a clear manifestation of excessive formation of free radical and activation of lipid peroxidation ${ }^{56}$. Fatty acids can modulate the cellular susceptibility to oxidative stress, probably due to changes of membrane FA composition ${ }^{54}$. 
Other liver integrity markers, such as ALT and AST, were assessed in the blood serum in the present experiment. Elevated levels of plasma ALT and AST are indicative of liver damage ${ }^{57}$. Although the ALT remained unchanged, the AST presented the highest concentration with HVF treatment, followed by RUM and minimal with CONT. Our results are consistent with the high correlation between TFA intake and blood AST in rats reported by Dhibi et al. ${ }^{56}$.

The adverse effects of TFA on metabolic parameters mentioned above may have predisposed the rats to the onset of non-alcoholic fatty liver disease (NAFLD) in the HVF group, as suggested by the histopathologic analysis of hepatic tissue. Previous studies have demonstrated that inflammation ${ }^{58}$, increased blood AST levels ${ }^{59}$, and oxidative stress ${ }^{56}$ are closely related to NAFLD's occurrence. Indeed, the direct disturbance effect of TFA on liver function is so that high-TFA diets have been used to induce NAFLD experimentally in some animal models ${ }^{60-62}$. Moreover, high-TFA diets might induce more severe liver steatosis than common high-fat diets, possibly through suppressing the enzyme adipose triglyceride lipase (ATGL) and subsequently promoting lipid accumulation in the liver ${ }^{63}$. Obara et al. ${ }^{64}$ have further demonstrated that excessive TFA consumption induces hepatic lipogenic gene expression and non-esterified FA influx into the liver, with the hepatic accumulation of lipid peroxide and local cytokines by Kupffer cells.

On the other hand, although RUM-fed rats showed mild inflammation in the histopathological evaluation of the liver, RUM treatment did not trigger negative metabolic changes, as discussed above. In fact, the RUM treated animals did not present as many fatty liver lesions as those from those fed HVF. Some caution is needed in the interpretation of the HVF effects on fatty liver lesions, as the FA accumulation in the liver was not detected. In fact, the liver FA concentration remained normal and similar among the three treatments.

The much lower incorporation of TFA in the liver observed with RUM than with HVF could explain why the rats fed RUM did not develop the HFD-induced NAFLD. In fact, besides 18:1 t11, all the concentrations of the other trans-octadecenoates in the liver of RUM rats were not significantly different from the CONT. Vaccenic acid (18:1t11) was the overwhelming trans-octadecenoate present in the lamb fat used in the RUM diet. Vaccenic acid is usually the major TFA of edible ruminant fat, although, in ruminants kept under intensive feeding conditions, the $18: 1 t 10$ often replaces the $18: 1 t 11$ as the predominant TFA ${ }^{6}$. The $18: 1 t 11$ is also actively desaturated in mammals tissues by stearoyl-CoA desaturase (SCD) into 18:2c9,t11, the major CLA isomer present in ruminant fat ${ }^{6}$. Both $18: 1 t 11$ and $18: 2 c 9, t 11$ have been reported to reduce hepatic lipogenesis ${ }^{65}$. In fact, despite being a TFA, the 18:1 111 seems very effective in attenuating complications observed in the metabolic syndrome in rats ${ }^{66}$, decreasing the adipocyte size and increasing the levels of IL-10 in adipose tissue $^{67}$, and preventing hepatic lipid accumulation ${ }^{68}$.

Liver and the other tissues of the rats fed RUM also had consistently more iso- and anteiso-BCFA, and 18:0 than HVF and CONT. Thus we can hypothesise that some of these FA might have protective effects on the liver. Indeed, a study showed that a stearic acid-rich diet combined with cell therapy accelerated the recovery of hepatic dysfunction in a rat model of liver injury ${ }^{69}$. Thus, further experimental studies are needed to assess the individual metabolic effects of BCFA and 18:0. 
At the present experimental conditions, (i.e., diets with $23 \%$ of fat, fed for 7 weeks) RUM seems more effective in reshaping the gut microbiota than HVT as suggested by significant group dissimilarities. It is well established that HFD induced digestive dysbiosis in rodents, although it may require longer feeding periods to gut dysbiosis be fully express ${ }^{70}$. Diets rich in vegetable fat, irrespective of its TFA content, can impact microbial composition more than low-fat diets ${ }^{71}$. In a meta-analysis, Bisanz et al. ${ }^{72}$ demonstrated that the use of HFD in the range of 27.1 to $65 \%$ fat might induce reproducible shifts in the rat gut microbiota, such as changes in the Firmicutes/Bacteroidetes ratio. Depletion of Blautia and Lachnospiraceaehas has been frequently reported in rats under systemic inflammation conditions ${ }^{73,74}$. Therefore, the increased abundances of these bacteria observed in the gut of rats receiving RUM could be associated with the low levels of inflammatory markers such as MDA and cytokines. These results warrant further investigations on functional approaches addressing the effects of Blautia and Lachnospiraceae organisms on the systemic metabolism.

The reduction of fibrolytic bacteria such as Monoglobus and Prevotella caused by the consumption of highfat diets corroborate previous findings ${ }^{75,76}$ and suggest that long-term use of HFD may pose undesirable changes in the gut microbial composition of rats.

\section{Conclusion}

It is noticeable that the source of dietary TFA (industrial vs ruminant) have a considerable but distinct influence on rats' metabolism, and that ruminant fat might reduce risk parameters involved in the development of cardiovascular diseases.

\section{Declarations}

\section{Data availability}

The datasets generated during and/or analyzed during the current study are available from the corresponding author upon reasonable request.

\section{Acknowledgment}

The authors give thanks to Francinilda Alves de Sousa of the Animal Husbandry Department, Centre for Agrarian Sciences, Federal University of Paraíba, Areia-PB, Brazil for the ruminant fat used in the present study. This work was supported by the de Coordenacao de Aperfeicoamento de Pessoal de Nivel Superior Brazil (CAPES), Brazil (Finance Code 001)

\section{Author contributions}

L.B.M., R.J.B., J.K.B.S., A.N.M., C.J.B.O., and R.C.R.E.Q. designed the experiment, L.B.M., R.J.B., and R.C.R.E.Q. wrote the mainmanuscript text, L.B.M., M.L.P.L., A.F.A., W.J. A., and C.J.B.O. prepared figures, L.B.M., C.N.M.C., G.C.B.G., D.F.S.A., L.T.T., A.S.S., A.F.A., M.L.P.L., and W.J. A. conducted lab experiments, J.S.A., and J.K.B.S. helped in write up of the manuscript. All authors have reviewed the manuscript.

\section{Competing interests}

Page 12/31 
The authors declare no competing interests.

\section{References}

1. Cascio, G. \& Schiera, G. \& Di Liegro, I. Dietary Fatty Acids in Metabolic Syndrome, Diabetes and Cardiovascular Diseases. Curr. Diabetes Rev.8, 2-17 (2011).

2. Wang, D. D. \& Hu, F. B. Dietary Fat and Risk of Cardiovascular Disease: Recent Controversies and Advances. Annual Review of Nutrition.37, 423-446 (2017).

3. Hammad, S., Pu, S. \& Jones, P. J. Current Evidence Supporting the Link Between Dietary Fatty As and Cardiovascular Disease. Lipids vol. 51 507-517(2016).

4. Kuhnt, K., Degen, C. \& Jahreis, G. Evaluation of the Impact of Ruminant Trans Fatty Acids on Human Hcidealth: Important Aspects to Consider. Crit. Rev. Food Sci. Nutr.56, 1964-1980 (2016).

5. Takeuchi, H. \& Sugano, M. Industrial Trans Fatty Acid and Serum Cholesterol: The Allowable Dietary Level. J. Lipids.2017, 1-10 (2017).

6. Bessa, R. J. B., Alves, S. P. \& Santos-Silva, J. Constraints and potentials for the nutritional modulation of the fatty acid composition of ruminant meat. Eur. J. Lipid Sci. Technol.117, 1325-1344 (2015).

7. Mapiye, C. et al. The trans-octadecenoic fatty acid profile of beef: Implications for global food and nutrition security. Food Res. Int.76, 992-1000 (2015).

8. Aldai, N., de Renobales, M., Barron, L. J. R. \& Kramer, J. K. G. What are the trans fatty acids issues in foods after discontinuation of industrially produced trans fats? Ruminant products, vegetable oils, and synthetic supplements. Eur. J. Lipid Sci. Technol.115, 1378-1401 (2013).

9. Dugan, M. E. R. et al. Trans-forming beef to provide healthier fatty acid profiles. https://doi.org/10.1139/CJAS 2011-04491, 545-556 (2011).

10. Mann, N. Human evolution and diet: a modern conundrum of health versus meat consumption, or is it? Anim. Prod. Sci.53, 1135 (2013).

11. Shingfield, K. J., Bonnet, M. \& Scollan, N. D. Recent developments in altering the fatty acid composition of ruminant-derived foods. in Animalvol. 7 132-162 (Animal, 2013).

12. Brouwer, I. A., Wanders, A. J. \& Katan, M. B. Trans fatty acids and cardiovascular health: Research completed? European Journal of Clinical Nutrition.67, 541-547 (2013).

13. Décarie-Spain, L. et al. Nucleus accumbens inflammation mediates anxiodepressive behavior and compulsive sucrose seeking elicited by saturated dietary fat. Mol. Metab.10, 1-13 (2018).

14. Bendsen, N. T., Christensen, R., Bartels, E. M. \& Astrup, A. Consumption of industrial and ruminant trans fatty acids and risk of coronary heart disease: A systematic review and meta-analysis of cohort studies. European Journal of Clinical Nutrition.65, 773-783 (2011).

15. Roe, M. et al. Trans fatty acids in a range of UK processed foods. Food Chem.140, 427-431 (2013).

16. WHO | World Health Organization. Diet, nutrition and the prevention of chronic diseases. WHO(2014).

17. WHO | World Health Organization. A comprehensive global monitoring framework including indicators and a set of voluntary global targets for the prevention and control of non communicabale diseases, WHO (2012). 
18. Ministério da Saúde.

http://bvsms.saude.gov.br/bvs/saudelegis/anvisa/2003/rdc0360_23_12_2003.html.

19. Mokkala, K., Houttu, N., Cansev, T. \& Laitinen, K. Interactions of dietary fat with the gut microbiota: Evaluation of mechanisms and metabolic consequences. Clin. Nutr.39, 994-1018 (2020).

20. Kübeck, R. et al. Dietary fat and gut microbiota interactions determine diet-induced obesity in mice. Mol. Metab.5, 1162-1174 (2016).

21. Rastelli, M., Knauf, C. \& Cani, P. D. Gut Microbes and Health: A Focus on the Mechanisms Linking Microbes, Obesity, and Related Disorders. Obesity vol. 26 792-800(2018).

22. Nagy, K. \& Tiuca, I. D. Importance of Fatty Acids in Physiopathology of Human Body. in Fatty Acids(InTech, 2017). doi:10.5772/67407.

23. Müller, C. P. et al. Brain membrane lipids in major depression and anxiety disorders. Biochimica et Biophysica Acta - Molecular and Cell Biology of Lipids.1851, 1052-1065 (2015).

24. Alves, S. P., Raundrup, K., Cabo, Ã., Bessa, R. J. B. \& Almeida, A. M. Fatty Acid Composition of Muscle, Adipose Tissue and Liver from Muskoxen (Ovibos moschatus) Living in West Greenland. PLoS One.10, e0145241 (2015).

25. Winterbourn, C. C., Gutteridge, J. M. C. \& Halliwell, B. Doxorubicin-dependent lipid peroxidation at low partial pressures of 02. J. Free Radicals Biol. Med.1, 43-49 (1985).

26. Brand-Williams, W., Cuvelier, M. E. \& Berset, C. Use of a Free Radical Method to Evaluate Antioxidant Activity. vol. 28 (1995).

27. Batista, K. S. et al. Beneficial effects of consumption of acerola, cashew or guava processing byproducts on intestinal health and lipid metabolism in dyslipidaemic female Wistar rats. Br. J. Nutr.119, 30-41 (2018).

28. Bolyen, E. et al. Reproducible, interactive, scalable and extensible microbiome data science using QIIME 2. Nature Biotechnology.37, 852-857 (2019).

29. Callahan, B. J. et al. DADA2: High-resolution sample inference from Illumina amplicon data. Nat. Methods.13, 581-583 (2016).

30. Janssen, S. et al. Phylogenetic Placement of Exact Amplicon Sequences Improves Associations with Clinical Information. mSystems 3(2018).

31. McMurdie, P. J. \& Holmes, S. phyloseq: An R Package for Reproducible Interactive Analysis and Graphics of Microbiome Census Data. PLoS One.8, e61217 (2013).

32. McDonald, D. et al. An improved Greengenes taxonomy with explicit ranks for ecological and evolutionary analyses of bacteria and archaea. ISME J.6, 610-618 (2012).

33. Gish, W., Altschul, S. F., Lipman, D. J., Miller, W. \& Myers, E. W. Basic local alignment search tool. J. Mol. Biol.https://doi.org/10.1016/S0022-2836(05)80360-2 (1990).

34. Carro, A. \& Panisello, J. M. Deciphering the Riddles in Nutrition and Cardiovascular Disease. Eur. Cardiol. Rev.14, 141-150 (2019).

35. Crescenzo, R. et al. Fat quality influences the obesogenic effect of high fat diets. Nutrients.7, 9475-9491 (2015). 
36. Duca, F. A., Sakar, Y. \& Covasa, M. The modulatory role of high fat feeding on gastrointestinal signals in obesity. Journal of Nutritional Biochemistry.24, 1663-1677 (2013).

37. Shen, M. C., Zhao, X., Siegal, G. P., Desmond, R. \& Hardy, R. W. Dietary stearic acid leads to a reduction of visceral adipose tissue in athymic nude mice.PLoS One9, (2014).

38. Fernandez, M. L. \& West, K. L. Mechanisms by which dietary fatty acids modulate plasma lipids. J. Nutr.135, 2075-2078 (2005).

39. de Almeida, M. M. et al. Cis-9, trans-11 and trans-10, cis-12 CLA Mixture does not change body composition, induces insulin resistance and increases serum hdl cholesterol level in rats. J. Oleo Sci.64, 539-551 (2015).

40. De Almeida, M. M. et al. Butter naturally enriched in cis-9, trans-11 CLA prevents hyperinsulinemia and increases both serum HDL cholesterol and triacylglycerol levels in rats. Lipids Health Dis.13, (2014).

41. Nestel, P., Fujii, A. \& Allen, T. The cis-9,trans-11 isomer of conjugated linoleic acid (CLA) lowers plasma triglyceride and raises HDL cholesterol concentrations but does not suppress aortic atherosclerosis in diabetic apoE-deficient mice. Atherosclerosis.189, 282-287 (2006).

42. Maslak, E. et al. Individual CLA isomers, c9t11 and t10c12, prevent excess liver glycogen storage and inhibit lipogenic genes expression induced by high-fructose diet in rats. Biomed Res. Int. 2015, (2015).

43. Haas, M. J. \& Mooradian, A. D. Inflammation, high-density lipoprotein and cardiovascular dysfunction. Curr. Opin. Infect. Dis.24, 265-272 (2011).

44. Ference, B. A. et al. Low-density lipoproteins cause atherosclerotic cardiovascular disease. 1. Evidence from genetic, epidemiologic, and clinical studies. A consensus statement fromthe European Atherosclerosis Society Consensus Panel. Eur. Heart J.38, 2459-2472 (2017).

45. WHO | Fats and fatty acids in human nutrition. WHO(2014).

46. Da Silva, M. S. et al. Modulation of the biomarkers of inflammation and oxidative stress by ruminant trans fatty acids and dairy proteins in vascular endothelial cells (HUVEC). Prostaglandins Leukot. Essent. Fat. Acids.126, 64-71 (2017).

47. Ahn, I. S. et al. Isomer-specific effect of conjugated linoleic acid on inflammatory adipokines associated with fat accumulation in 3T3-L1 adipocytes. J. Med. Food.9, 307-312 (2006).

48. Dhibi, M. et al. Consumption of Oxidized and Partially Hydrogenated Oils Differentially Induces TransFatty Acids Incorporation in Rats' Heart and Dyslipidemia. J. Am. Coll. Nutr.35, 125-135 (2016).

49. Liu, M., Chen, J., Huang, D., Ke, J. \& Wu, W. A meta-analysis of pro-inflammatory cytokines in chronic heart failure. Heart Asia.6, 130-136 (2014).

50. Kosmas, C. E. et al. Anti-inflammatory therapy for cardiovascular disease. Ann. Transl. Med.7, 147-147 (2019).

51. Grebe, A., Hoss, F. \& Latz, E. NLRP3 inflammasome and the IL-1 pathway in atherosclerosis. Circul. Res.122, 1722-1740 (2018).

52. Monguchi, T. et al. Excessive intake of trans fatty acid accelerates atherosclerosis through promoting inflammation and oxidative stress in a mouse model of hyperlipidemia. J. Cardiol.70, 121-127 (2017).

53. Machado, R. M. et al. Omega-6 polyunsaturated fatty acids prevent atherosclerosis development in LDLr$\mathrm{KO}$ mice, in spite of displaying a pro-inflammatory profile similar to trans fatty acids. 
Atherosclerosis.224, 66-74 (2012).

54. Mozaffarian, D. et al. trans Fatty acids and systemic inflammation in heart failure. Am. J. Clin. Nutr.80, $1521-1525$ (2004).

55. Rao, Y. P. C. \& Lokesh, B. R. Down-regulation of NF-kB expression by n-3 fatty acid-rich linseed oil is modulated by PPARy activation, eicosanoid cascade and secretion of cytokines by macrophages in rats fed partially hydrogenated vegetable fat. Eur. J. Nutr.56, 1135-1147 (2017).

56. Dhibi, M. et al. The intake of high fat diet with different trans fatty acid levels differentially induces oxidative stress and non alcoholic fatty liver disease (NAFLD) in rats.Nutr. Metab.8, (2011).

57. McGill, M. R. The past and present of serum aminotransferases and the future of liver injury biomarkers. EXCL/ J.15, 817-828 (2016).

58. Tilg, H. The role of cytokines in non-alcoholic fatty liver disease. Dig. Dis.28, 179-185 (2010).

59. Helal, M. G., Ayoub, S. E., Elkashefand, W. F. \& Ibrahim, T. M. Caffeine affects HFD-induced hepatic steatosis by multifactorial intervention. Hum. Exp. Toxicol.37, 983-990 (2018).

60. Liu, W. H., Lin, C. C., Wang, Z. H., Mong, M. C. \& Yin, M. C. Effects of protocatechuic acid on trans fat induced hepatic steatosis in mice. J. Agric. Food Chem.58, 10247-10252 (2010).

61. Santos, J. D. B. et al. Food-drug interaction: Anabolic steroids aggravate hepatic lipotoxicity and nonalcoholic fatty liver disease induced by trans fatty acids. Food Chem. Toxicol.116, 360-368 (2018).

62. Komatsu, G. et al. AlM-deficient mouse fed a high-trans fat, high-cholesterol diet: A new animal model for non-alcoholic fatty liver disease. Exp. Anim.68, 147-158 (2019).

63. Zhao, X. et al. Trans-fatty acids aggravate obesity, insulin resistance and hepatic steatosis in C57BL/6 mice, possibly by suppressing the IRS1 dependent pathway.Molecules21, (2016).

64. Obara, N. et al. Possible involvement and the mechanisms of excess trans-fatty acid consumption in severe NAFLD in mice. J. Hepatol.53, 326-334 (2010).

65. Jacome-Sosa, M. M. et al. Increased hypolipidemic benefits of cis- 9 , trans- 11 conjugated linoleic acid in combination with trans-11 vaccenic acid in a rodent model of the metabolic syndrome, the JCR:LA-cP rat. Nutr. Metab.7, 60 (2010).

66. Wang, Y. et al. Trans-11 Vaccenic Acid Reduces Hepatic Lipogenesis and Chylomicron Secretion in JCR:LA-cp Rats. J. Nutr.139, 2049-2054 (2009).

67. Mohankumar, S. K. et al. Dietary supplementation of trans-11-vaccenic acid reduces adipocyte size but neither aggravates nor attenuates obesity-mediated metabolic abnormalities in fa/fa Zucker rats. Br. J. Nutr.109, 1628-1636 (2013).

68. Jacome-Sosa, M. M. et al. Diets enriched in trans-11 vaccenic acid alleviate ectopic lipid accumulation in a rat model of NAFLD and metabolic syndrome. J. Nutr. Biochem.25, 692-701 (2014).

69. Goradel, N. H. et al. Improvement of liver cell therapy in rats by dietary stearic acid. Iran. Biomed. J.20, 217-222 (2016).

70. He, C. et al. High-Fat Diet Induces Dysbiosis of Gastric Microbiota Prior to Gut Microbiota in Association With Metabolic Disorders in Mice. Front. Microbiol.9, 639 (2018). 
71. Ge, Y. et al. Effect of industrial trans-fatty acids-enriched diet on gut microbiota of C57BL/6 mice. Eur. J. Nutr.58, 2625-2638 (2019).

72. Bisanz, J. E., Upadhyay, V., Turnbaugh, J. A., Ly, K. \& Turnbaugh, P. J. Meta-Analysis Reveals Reproducible Gut Microbiome Alterations in Response to a High-Fat Diet. Cell Host Microbe.26, 265-2724 (2019).

73. Zhu, Y. et al. Gut microbiota dysbiosis worsens the severity of acute pancreatitis in patients and mice. J. Gastroenterol.54, 347-358 (2019).

74. Zheng, J. et al. Improvement on metabolic syndrome in high fat diet-induced obese mice through modulation of gut microbiota by Sangguayin decoction.J. Ethnopharmacol.246, (2020).

75. Chen, T. et al. Fiber-utilising capacity varies in Prevotella- versus Bacteroides-dominated gut microbiota.Sci. Rep.7, (2017).

76. Kim, C. C. et al. Genomic insights from Monoglobus pectinilyticus: a pectin-degrading specialist bacterium in the human colon. ISME J.13, 1437-1456 (2019).

\section{Tables}

Table 1 - Fatty acid (FA) content (mg/g dry matter (DM)) and profile (g/100 g of total FA) of control diet (CONT) and of diets supplemented with hydrogenated vegetable fat (HVF) or ruminant fat (RUM). 


\begin{tabular}{|c|c|c|c|}
\hline & \multicolumn{3}{|c|}{ DIETS } \\
\hline & CONT & HVF & RUM \\
\hline $\mathrm{FA}, \mathrm{mg} / \mathrm{g} \mathrm{DM}$ & 41 & 226 & 255 \\
\hline \multicolumn{4}{|l|}{$F A(g / 100 g F A)$} \\
\hline \multicolumn{4}{|l|}{ Saturated } \\
\hline 10:0 & - & 0.07 & 0.10 \\
\hline $12: 0$ & - & 1.08 & 0.06 \\
\hline $\mathrm{i}-14: 0$ & - & - & 0.05 \\
\hline $14: 0$ & 0.10 & 0.58 & 2.35 \\
\hline i-15:0 & - & - & 0.24 \\
\hline$a-15: 0$ & - & - & 0.21 \\
\hline $15: 0$ & - & - & 0.39 \\
\hline $\mathrm{i}-16: 0$ & - & - & 0.15 \\
\hline $16: 0$ & 14.1 & 13.4 & 21.7 \\
\hline $\mathrm{i}-17: 0$ & - & - & 0.29 \\
\hline a-17:0 & - & - & 0.48 \\
\hline $17: 0$ & 0.12 & 0.12 & 0.99 \\
\hline 18:0 & 3.18 & 9.24 & 29.8 \\
\hline $20: 0$ & 0.37 & 0.35 & 0.21 \\
\hline $22: 0$ & 0.31 & 0.40 & 0.07 \\
\hline $23: 0$ & - & 0.05 & - \\
\hline $24: 0$ & - & 0.17 & - \\
\hline \multicolumn{4}{|l|}{ Monounsaturated } \\
\hline 16:1c7 & - & - & 0.36 \\
\hline $16: 1 \mathrm{c} 9$ & 0.11 & 0.10 & 0.64 \\
\hline 17:1c9 & - & 0.05 & 0.21 \\
\hline 18:1t6/t7/t8 & - & 2.86 & 0.42 \\
\hline $18: 1 \mathrm{t} 9$ & - & 4.61 & 0.47 \\
\hline $18: 1 \mathrm{t} 10$ & - & 6.61 & 0.50 \\
\hline 18:1t11 & - & 6.29 & 4.56 \\
\hline $18: 1 \mathrm{t} 12$ & - & 4.01 & 0.60 \\
\hline 18:1c9 & 24.3 & 24.4 & 25.4 \\
\hline 18:1c11 & 1.18 & 2.53 & 0.78 \\
\hline 18:1c12 & - & 2.99 & 0.15 \\
\hline 18:1c13 & - & 0.39 & 0.04 \\
\hline $18: 1 \mathrm{t} 16$ & - & 0.43 & 0.40 \\
\hline 18:1c15 & - & 0.19 & 0.06 \\
\hline 20:1c11 & - & 0.20 & 0.17 \\
\hline \multicolumn{4}{|l|}{ Polyunsaturated } \\
\hline $18: 2 \mathrm{oi}^{1}$ & - & 1.85 & 0.29 \\
\hline $18: 2 n-6$ & 51.7 & 15.8 & 6.80 \\
\hline
\end{tabular}




\begin{tabular}{lccc} 
18:3n-3 & 4.5 & 1.30 & 0.69 \\
$18: 2 \mathrm{c} 9 \mathrm{t} 11$ (CLA) & - & - & 0.50 \\
Sums & & & \\
$\Sigma$ SFA & 18.2 & 25.5 & 57.0 \\
$\Sigma$ MUFA & 25.6 & 55.6 & 34.7 \\
$\Sigma$ PUFA & 56.2 & 18.9 & 8.3 \\
strans FA & nd & 24.8 & 7.5 \\
B.FAA $^{2}$ & nd & nd & 1.4 \\
\hline
\end{tabular}

1 - sum of other isomers of $18: 2 n-6$

2 - sum of branched chain FA

Table 2 - Feed intake, body weight (BW) gain, and weight of selected tissues of adult rats CONT, HVF and RUM diets.

\begin{tabular}{lcccc}
\hline \multirow{2}{*}{ Variables } & \multicolumn{3}{c}{ Experimental Groups $^{1}$} & \multirow{2}{*}{$P$ value } \\
\cline { 2 - 4 } & CONT & HVF & RUM & \\
\hline Feed intake (g/kg BW) & $99.6 \pm 4.47^{\mathrm{a}}$ & $66.9 \pm 4.99^{\mathrm{b}}$ & $68.9 \pm 4.49^{\mathrm{b}}$ & $<0,001$ \\
Total feed intake (g) & $1652 \pm 27.1^{\mathrm{a}}$ & $1123 \pm 34.0^{\mathrm{b}}$ & $1231 \pm 30.6^{\mathrm{b}}$ & $<0,001$ \\
\hline BW gain (g) & $111 \pm 3.50$ & $123 \pm 4.06$ & $124 \pm 5.63$ & 0,101 \\
\hline Feed conversion rate & $14.8 \pm 0.59^{\mathrm{a}}$ & $8.90 \pm 0.43^{\mathrm{b}}$ & $7.95 \pm 0.51^{\mathrm{b}}$ & $<0,001$ \\
\hline Tissue weight (g/kg BW) & & & & \\
\hline \multicolumn{1}{c}{ Heart } & $3.78 \pm 0.10$ & $4.09 \pm 0.15$ & $3.81 \pm 0.14$ & 0,207 \\
\hline Liver & $31.3 \pm 0.59$ & $32.8 \pm 0.71$ & $32.1 \pm 0.84$ & 0,360 \\
\hline Adipose tissue & $30.1 \pm 1.46^{\mathrm{a}}$ & $25.5 \pm 3.96^{\mathrm{a}}$ & $15.4 \pm 2.26^{\mathrm{b}}$ & 0,004 \\
\hline
\end{tabular}

1 - CONT: Control; HVF: hydrogenated vegetable fat; RUM: ruminant fat.

2 - Abdominal and epididymal fat

Values expressed as mean and standard error (One-way ANOVA, Tukey).

Averages on the same line with significant differences $(p<0.05)$ are indicated by different letters.

Table 3 - Blood serum biochemistry parameters of adult rats fed CONT, HVF and RUM diets. 


\begin{tabular}{|c|c|c|c|c|}
\hline \multirow[t]{2}{*}{ Variables } & \multicolumn{3}{|c|}{ Experimental Groups ${ }^{1}$} & \multirow[t]{2}{*}{$P$ value } \\
\hline & CONT & HVF & RUM & \\
\hline \multicolumn{5}{|l|}{ Metabolites (mg/dL) } \\
\hline Glucose & $237 \pm 11.9$ & $228 \pm 14.2$ & $238 \pm 9.10$ & 0,828 \\
\hline Triglycerides & $39.4 \pm 2.29$ & $33.5 \pm 3.21$ & $34.5 \pm 2.67$ & 0,336 \\
\hline Total cholesterol & $39.7 \pm 2.24$ & $44.9 \pm 3.20$ & $46.4 \pm 1.78$ & 0.136 \\
\hline \multicolumn{5}{|c|}{ Lipoproteins $(\mathrm{mg} / \mathrm{dL})^{2}$} \\
\hline HDL & $30.9 \pm 0.72^{\mathrm{a}}$ & $27.8 \pm 2.64^{\mathrm{a}}$ & $37.4 \mathrm{~b} \pm 2.18^{\mathrm{b}}$ & 0,007 \\
\hline LDL & $12.8 \pm 0.79^{a}$ & $14.8 \pm 0.70^{\mathrm{a}}$ & $8.67 \pm 0.62^{b}$ & $<0,001$ \\
\hline VLDL & $7.94 \pm 0.75$ & $6.25 \pm 0.56$ & $6.90 \pm 0.53$ & 0,169 \\
\hline \multicolumn{5}{|l|}{ Transaminases $(\mathrm{U} / \mathrm{L})^{3}$} \\
\hline ALT & $47.8 \pm 2.54$ & $52.1 \pm 3.10$ & $52.0 \pm 2.60$ & 0,452 \\
\hline AST & $96 \pm 6.93^{a}$ & $142 \pm 8.25^{b}$ & $112 \pm 10.4^{\mathrm{ab}}$ & 0.005 \\
\hline
\end{tabular}

1 - CONT: Control; HVF: hydrogenated vegetable fat; RUM: ruminant fat.

2 - HDL: high density lipoprotein; LDL: low density lipoprotein; VLDL: very low density lipoprotein.

3 - ALT: alanine aminotransferase; AST: aspartate aminotransferase.

Averages on the same line with significant differences $(p<0.05)$ are indicated by different letters.

Table 4 - Fatty acid composition (mg/g dry tissue) of liver of adult rats fed CONT, HVF and R diets. 


\begin{tabular}{|c|c|c|c|c|}
\hline \multirow[t]{2}{*}{ Fatty acids } & \multicolumn{3}{|c|}{ Experimental Groups ${ }^{1}$} & \multirow[t]{2}{*}{$P$ value } \\
\hline & CONT & HVF & RUM & \\
\hline $14: 0$ & $0.41 \pm 0.155$ & $0.12 \pm 0.167$ & $0.18 \pm 0.154$ & 0.407 \\
\hline $15: 0$ & $0.16 \pm 0.025$ & $0.07 \pm 0.027$ & $0.15 \pm 0.025$ & 0.046 \\
\hline i-16:0 & $0.04^{\mathrm{ab}} \pm 0.009$ & $0.01^{\mathrm{b}} \pm 0.009$ & $0.05^{\mathrm{a}} \pm 0.009$ & 0.014 \\
\hline $16: 0$ & $20.1 \pm 2.793$ & $10.3 \pm 3.016$ & $12.7 \pm 2.793$ & 0.068 \\
\hline $16: 1-t$ & $0.02^{\mathrm{c}} \pm 0.033$ & $0.42^{\mathrm{a}} \pm 0.036$ & $0.16^{\mathrm{b}} \pm 0.033$ & $<0.001$ \\
\hline i-1 $7: 0$ & $0.05 \pm 0.009$ & $0.06 \pm 0.010$ & $0.08 \pm 0.009$ & 0.157 \\
\hline $16: 1-C 7$ & $0.13 \pm 0.029$ & $0.24 \pm 0.032$ & $0.18 \pm 0.029$ & 0.080 \\
\hline $16: 1-c 9$ & $1.37 \pm 0.455$ & $0.13 \pm 0.492$ & $0.19 \pm 0.455$ & 0.133 \\
\hline $\mathrm{a}-17: 0$ & $0.03 \pm 0.011$ & nd & $0.11 \pm 0.011$ & $<0.001$ \\
\hline $17: 0$ & $0.45^{\mathrm{a}} \pm 0.024$ & $0.17^{\mathrm{b}} \pm 0.026$ & $0.50^{\mathrm{a}} \pm 0.024$ & $<0.001$ \\
\hline $\mathrm{i}-18: 0$ & $0.23^{\mathrm{a}} \pm 0.021$ & $0.05^{\mathrm{b}} \pm 0.022$ & $0.04^{b} \pm 0.021$ & $<0.001$ \\
\hline $17: 1-c 9$ & $0.07^{\mathrm{a}} \pm 0.015$ & $0.01^{\mathrm{b}} \pm 0.017$ & $0.06^{\mathrm{ab}} \pm 0.015$ & 0.044 \\
\hline $18: 0$ & $23.1^{\mathrm{b}} \pm 0.961$ & $19.8^{\mathrm{b}} \pm 1.038$ & $27.7^{\mathrm{a}} \pm 0.961$ & $<0.001$ \\
\hline $18: 1-t 6 /-t 7 /-t 8$ & $0.03^{b} \pm 0.041$ & $0.63^{\mathrm{a}} \pm 0.044$ & $0.11^{\mathrm{b}} \pm 0.041$ & $<0.001$ \\
\hline $18: 1-t 9$ & $0.08^{\mathrm{b}} \pm 0.084$ & $1.73^{\mathrm{a}} \pm 0.091$ & $0.17^{\mathrm{b}} \pm 0.084$ & $<0.001$ \\
\hline $18: 1-t 10$ & $0.04^{\mathrm{b}} \pm 0.060$ & $0.96^{\mathrm{a}} \pm 0.065$ & $0.10^{\mathrm{b}} \pm 0.06$ & $<0.001$ \\
\hline $18: 1-t 11$ & $0.18^{\mathrm{c}} \pm 0.105$ & $1.83^{\mathrm{a}} \pm 0.113$ & $1.05^{\mathrm{b}} \pm 0.105$ & $<0.001$ \\
\hline $18: 1-t 12$ & $0.06^{\mathrm{b}} \pm 0.083$ & $2.39^{\mathrm{a}} \pm 0.090$ & $0.30^{\mathrm{b}} \pm 0.083$ & $<0.001$ \\
\hline $18: 1-c 9$ & $12.7 \pm 3.914$ & $8.41 \pm 4.228$ & $10.5 \pm 3.914$ & 0.763 \\
\hline $18: 1-t 15$ & nd & $0.18 \pm 0.029$ & $0.10 \pm 0.027$ & 0.001 \\
\hline $18: 1-c 11$ & $2.17^{\mathrm{a}} \pm 0.199$ & $1.38^{\mathrm{b}} \pm 0.215$ & $1.01^{\mathrm{b}} \pm 0.199$ & 0.002 \\
\hline $18: 1-c 12$ & $0.13^{\mathrm{b}} \pm 0.043$ & $0.93^{\mathrm{a}} \pm 0.046$ & $0.07^{\mathrm{b}} \pm 0.043$ & $<0.001$ \\
\hline $18: 1-c 13$ & $0.05^{\mathrm{b}} \pm 0.010$ & $0.12^{\mathrm{a}} \pm 0.011$ & $0.04^{\mathrm{b}} \pm 0.010$ & $<0.001$ \\
\hline $18: 1-t 16 /-c 14$ & $0.04^{\mathrm{b}} \pm 0.011$ & $0.16^{\mathrm{a}} \pm 0.012$ & $0.18^{\mathrm{a}} \pm 0.011$ & $<0.001$ \\
\hline $18: 1-c 15$ & nd & $0.05 \pm 0.004$ & $0.02 \pm 0.003$ & $<0.001$ \\
\hline $18: 2 \mathrm{oi}$ & $0.03^{b} \pm 0.031$ & $0.39^{\mathrm{a}} \pm 0.034$ & $0.11^{\mathrm{b}} \pm 0.031$ & $<0.001$ \\
\hline $18: 2 n-6$ & $18.8 \pm 2.343$ & $14.1 \pm 2.531$ & $12.3 \pm 2.343$ & 0.165 \\
\hline $20: 0$ & $0.09 \pm 0.015$ & $0.05 \pm 0.016$ & $0.05 \pm 0.015$ & 0.114 \\
\hline $18: 3 n-6$ & $0.13 \pm 0.016$ & $0.08 \pm 0.018$ & $0.12 \pm 0.016$ & 0.158 \\
\hline $20: 1$ & $0.18^{\mathrm{a}} \pm 0.028$ & $0.06^{\mathrm{b}} \pm 0.030$ & $0.05^{\mathrm{b}} \pm 0.028$ & 0.006 \\
\hline $18: 3 n-3 / 20: 1-c 11$ & $0.41 \pm 0.104$ & $0.18 \pm 0.112$ & $0.20 \pm 0.104$ & 0.250 \\
\hline $18: 2-c 9 t 11$ & $0.03^{b} \pm 0.024$ & $0.06^{\mathrm{b}} \pm 0.026$ & $0.16^{\mathrm{a}} \pm 0.024$ & 0.003 \\
\hline
\end{tabular}




\begin{tabular}{ccccc}
$20: 2 \mathrm{n}-6$ & $0.23^{\mathrm{a}} \pm 0.018$ & $0.14^{\mathrm{b}} \pm 0.019$ & $0.12^{\mathrm{b}} \pm 0.018$ & 0.001 \\
\hline $20: 3 \mathrm{n}-9$ & $0.07^{\mathrm{b}} \pm 0.019$ & $0.08^{\mathrm{b}} \pm 0.020$ & $0.35^{\mathrm{a}} \pm 0.019$ & $<0.001$ \\
\hline $22: 0$ & $0.07^{\mathrm{b}} \pm 0.018$ & $0.12^{\mathrm{ab}} \pm 0.020$ & $0.13^{\mathrm{a}} \pm 0.018$ & 0.036 \\
\hline $20: 3 \mathrm{n}-6$ & $0.41^{\mathrm{b}} \pm 0.097$ & $0.75^{\mathrm{ab}} \pm 0.104$ & $0.94^{\mathrm{a}} \pm 0.097$ & 0.004 \\
\hline $20: 4 \mathrm{n}-6$ & $23.9 \pm 1.47$ & $23.3 \pm 1.59$ & $25.3 \pm 1.47$ & 0.627 \\
\hline $23: 0$ & $0.16 \pm 0.018$ & $0.14 \pm 0.020$ & $0.13 \pm 0.018$ & 0.611 \\
\hline $20: 5 \mathrm{n}-3$ & $0.08^{\mathrm{b}} \pm 0.024$ & $0.09^{\mathrm{b}} \pm 0.026$ & $0.19^{\mathrm{a}} \pm 0.024$ & 0.009 \\
\hline $22: 4 \mathrm{n}-6$ & $0.35^{\mathrm{a}} \pm 0.033$ & $0.22^{\mathrm{b}} \pm 0.035$ & $0.26^{\mathrm{ab}} \pm 0.033$ & 0.040 \\
\hline $22: 5 \mathrm{n}-6$ & $0.19^{\mathrm{a}} \pm 0.024$ & $0.06^{\mathrm{b}} \pm 0.026$ & $0.13^{\mathrm{ab}} \pm 0.024$ & 0.010 \\
\hline $22: 5 \mathrm{n}-3$ & $0.41 \pm 0.064$ & $0.45 \pm 0.069$ & $0.47 \pm 0.064$ & 0.789 \\
\hline $22: 6 \mathrm{n}-3$ & $3.48 \pm 0.300$ & $2.81 \pm 0.324$ & $3.04 \pm 0.300$ & 0.320 \\
\hline Sums & & & & \\
\hline BCFA & $0.36^{\mathrm{a}} \pm 0.043$ & $0.12^{\mathrm{b}} \pm 0.046$ & $0.28^{\mathrm{a}} \pm 0.043$ & 0.005 \\
\hline SFA & $44.9^{\mathrm{a}} \pm 3.55$ & $31.0^{\mathrm{b}} \pm 3.83$ & $41.8^{\mathrm{ab}} \pm 3.55$ & 0.042 \\
\hline cis-MUFA & $16.6 \pm 4.604$ & $11.3 \pm 4.973$ & $12.1 \pm 4.604$ & 0.695 \\
\hline trans-MUFA & $0.41^{\mathrm{c}} \pm 0.389$ & $8.15^{\mathrm{a}} \pm 0.420$ & $1.99^{\mathrm{b}} \pm 0.389$ & $<0.001$ \\
\hline $\mathrm{n}-6$ PUFA & $44.0 \pm 2.400$ & $38.7 \pm 2.592$ & $39.2 \pm 2.400$ & 0.265 \\
\hline $\mathrm{n}-3$ PUFA & $4.38 \pm 0.314$ & $3.53 \pm 0.339$ & $3.90 \pm 0.314$ & 0.206 \\
\hline PUFA & $48.5 \pm 2.501$ & $42.7 \pm 2.702$ & $43.7 \pm 2.501$ & 0.260 \\
\hline
\end{tabular}

1 - CONT: Control; HVF: hydrogenated vegetable fat; RUM: ruminant fat.

Averages on the same line with significant differences $(p<0.05)$ are indicated by different letters.

Table 5 - Fatty acid composition of the adipose tissue of rats fed CONT, HVF and RUM diets (mg/g dry matter). 


\begin{tabular}{|c|c|c|c|c|}
\hline \multirow[t]{2}{*}{ Fatty acids } & \multicolumn{3}{|c|}{ Experimental Groups ${ }^{1}$} & \multirow[t]{2}{*}{$P$ value } \\
\hline & CONT & HVF & RUM & \\
\hline $12: 0$ & $0.60^{\mathrm{b}} \pm 0.327$ & $3.86^{\mathrm{a}} \pm 0.387$ & $1.04^{\mathrm{b}} \pm 0.306$ & $<0.001$ \\
\hline $\mathrm{i}-14: 0$ & $0.12 \pm 0.038$ & nd & $0.39 \pm 0.035$ & $<0.001$ \\
\hline 14:0 & $10.5^{\mathrm{a}} \pm 0.853$ & $5.47^{\mathrm{b}} \pm 1.009$ & $11.9^{\mathrm{a}} \pm 0.798$ & $<0.001$ \\
\hline $\mathrm{i}-15: 0$ & $0.29 \pm 0.040$ & nd & $1.01 \pm 0.040$ & $<0.001$ \\
\hline$a-15: 0$ & $0.16 \pm 0.045$ & nd & $1.06 \pm 0.042$ & $<0.001$ \\
\hline $14: 1-c 9$ & $0.72^{\mathrm{a}} \pm 0.061$ & $0.21^{\mathrm{b}} \pm 0.072$ & $0.40^{\mathrm{b}} \pm 0.061$ & $<0.001$ \\
\hline $15: 0$ & $2.59^{\mathrm{a}} \pm 0.354$ & $1.07^{\mathrm{b}} \pm 0.419$ & $3.71^{\mathrm{a}} \pm 0.332$ & $<0.001$ \\
\hline $\mathrm{i}-16: 0$ & $0.82^{\mathrm{b}} \pm 0.121$ & $0.24^{\mathrm{C}} \pm 0.143$ & $1.38^{\mathrm{a}} \pm 0.113$ & $<0.001$ \\
\hline $16: 0$ & $231^{\mathrm{a}} \pm 11.3$ & $123^{c} \pm 13.3$ & $169^{\mathrm{b}} \pm 10.5$ & $<0.001$ \\
\hline $16: 1-t$ & $0.43^{\mathrm{c}} \pm 0.286$ & $4.50^{\mathrm{a}} \pm 0.313$ & $2.29^{\mathrm{b}} \pm 0.248$ & $<0.001$ \\
\hline $\mathrm{i}-17: 0$ & $0.71^{\mathrm{b}} \pm 0.164$ & $0.55^{\mathrm{b}} \pm 0.194$ & $1.96^{\mathrm{a}} \pm 0.154$ & $<0.001$ \\
\hline $16: 1-c 7$ & $3.64^{\mathrm{a}} \pm 0.318$ & $2.18^{\mathrm{b}} \pm 0.376$ & $4.17^{\mathrm{a}} \pm 0.298$ & 0.002 \\
\hline $16: 1-c 9$ & $37.5^{\mathrm{a}} \pm 2.37$ & $11.3^{\mathrm{b}} \pm 2.80$ & $16.1^{\mathrm{b}} \pm 2.22$ & $<0.001$ \\
\hline a-17:0 & $0.68^{\mathrm{b}} \pm 0.235$ & $0.21^{\mathrm{b}} \pm 0.278$ & $2.42^{\mathrm{a}} \pm 0.220$ & $<0.001$ \\
\hline $17: 0$ & $2.47^{b} \pm 0.473$ & $1.44^{\mathrm{b}} \pm 0.559$ & $5.49^{\mathrm{a}} \pm 0.442$ & $<0.001$ \\
\hline i-1 $8: 0$ & $1.04^{\mathrm{a}} \pm 0.097$ & $0.36^{\mathrm{b}} \pm 0.115$ & $0.73^{\mathrm{a}} \pm 0.091$ & 0.001 \\
\hline $17: 1-c 9$ & $1.96^{\mathrm{a}} \pm 0.256$ & $0.85^{\mathrm{b}} \pm 0.303$ & $2.79^{\mathrm{a}} \pm 0.240$ & $<0.001$ \\
\hline $18: 0$ & $37.2^{\mathrm{b}} \pm 7.87$ & $42.8^{b} \pm 9.31$ & $103.1^{\mathrm{a}} \pm 7.36$ & $<0.001$ \\
\hline $18: 1-t 6 /-t 7 /-t 8$ & $0.25^{\mathrm{b}} \pm 1.707$ & $19.5^{\mathrm{a}} \pm 2.02$ & $5.56^{\mathrm{b}} \pm 1.59$ & $<0.001$ \\
\hline $18: 1-t 9$ & $0.53^{\mathrm{b}} \pm 2.819$ & $32.6^{\mathrm{a}} \pm 3.34$ & $8.08^{b} \pm 2.637$ & $<0.001$ \\
\hline $18: 1-t 10$ & $0.54^{\mathrm{b}} \pm 2.224$ & $27.7^{\mathrm{a}} \pm 2.63$ & $6.68^{\mathrm{b}} \pm 2.080$ & $<0.001$ \\
\hline $18: 1-t 11$ & $1.55^{\mathrm{b}} \pm 1.671$ & $31.7^{\mathrm{a}} \pm 1.98$ & $28.9^{\mathrm{a}} \pm 1.56$ & $<0.001$ \\
\hline $18: 1-t 12$ & $0.66^{\mathrm{b}} \pm 2.131$ & $24.1^{\mathrm{a}} \pm 2.522$ & $5.46^{\mathrm{b}} \pm 1.994$ & $<0.001$ \\
\hline $18: 1-c 9$ & $330^{\mathrm{b}} \pm 15.802$ & $280^{\mathrm{b}} \pm 18.7$ & $414^{\mathrm{a}} \pm 14.8$ & $<0.001$ \\
\hline $18: 1-t 15$ & nd & $7.80 \pm 0.969$ & $3.20 \pm 0.819$ & $<0.001$ \\
\hline $18: 1-c 11$ & $24.1^{\mathrm{a}} \pm 1.25$ & $24.2^{\mathrm{a}} \pm 1.47$ & $16.1^{\mathrm{b}} \pm 1.17$ & $<0.001$ \\
\hline $18: 1-c 12$ & $0.52^{\mathrm{b}} \pm 1.648$ & $19.8^{\mathrm{a}} \pm 1.95$ & $3.55^{\mathrm{b}} \pm 1.541$ & $<0.001$ \\
\hline $18: 1-c 13$ & $0.67^{\mathrm{b}} \pm 0.170$ & $2.38^{\mathrm{a}} \pm 0.201$ & $0.56^{\mathrm{b}} \pm 0.159$ & $<0.001$ \\
\hline $18: 1-t 16 /-c 14$ & $0.15^{\mathrm{b}} \pm 0.094$ & $1.41^{\mathrm{a}} \pm 0.103$ & $1.66^{\mathrm{a}} \pm 0.081$ & $<0.001$ \\
\hline $18: 1-c 15$ & nd & $0.73 \pm 0.060$ & $0.26 \pm 0.048$ & $<0.001$ \\
\hline 18:2oi & $0.87^{\mathrm{C}} \pm 0.846$ & $14.2^{\mathrm{a}} \pm 1.00$ & $4.76^{b} \pm 0.792$ & $<0.001$ \\
\hline $18: 2 n-6$ & & & & $<0.001$ \\
\hline
\end{tabular}




\begin{tabular}{|c|c|c|c|c|}
\hline & $301^{\mathrm{a}} \pm 10.2$ & $186^{\mathrm{b}} \pm 12.0$ & $151^{\mathrm{b}} \pm 9.5$ & \\
\hline $19: 1$ & $0.25^{c} \pm 0.061$ & $0.91^{\mathrm{b}} \pm 0.072$ & $1.29^{\mathrm{a}} \pm 0.057$ & $<0.001$ \\
\hline $20: 0$ & $0.80 \pm 0.100$ & $0.82 \pm 0.119$ & $0.93 \pm 0.094$ & 0.583 \\
\hline $18: 3 n-6$ & $0.79^{\mathrm{a}} \pm 0.040$ & $0.24^{\mathrm{b}} \pm 0.048$ & $0.26^{\mathrm{b}} \pm 0.038$ & $<0.001$ \\
\hline $20: 1$ & $14.6^{\mathrm{a}} \pm 0.472$ & $9.28^{\mathrm{b}} \pm 0.559$ & $7.88^{\mathrm{b}} \pm 0.442$ & $<0.001$ \\
\hline $18: 3 n-3 / 20: 1-c 11$ & $2.55^{\mathrm{a}} \pm 0.259$ & $1.13^{\mathrm{b}} \pm 0.306$ & $1.37^{\mathrm{b}} \pm 0.242$ & 0.004 \\
\hline $18: 2-c 9 t 11$ & $0.95^{\mathrm{c}} \pm 0.611$ & $4.52^{\mathrm{b}} \pm 0.723$ & $8.46^{\mathrm{a}} \pm 0.571$ & $<0.001$ \\
\hline $20: 2 n-6$ & $1.60^{\mathrm{a}} \pm 0.102$ & $0.37^{\mathrm{b}} \pm 0.121$ & $0.34^{\mathrm{b}} \pm 0.095$ & $<0.001$ \\
\hline $20: 3 n-9$ & $0.36^{\mathrm{a}} \pm 0.041$ & $0.08^{\mathrm{b}} \pm 0.049$ & $0.33^{\mathrm{a}} \pm 0.039$ & $<0.001$ \\
\hline $22: 0$ & $0.19 \pm 0.044$ & $0.33 \pm 0.048$ & $0.20 \pm 0.044$ & 0.086 \\
\hline $20: 3 n-6$ & $1.00^{\mathrm{a}} \pm 0.065$ & $0.26^{\mathrm{b}} \pm 0.077$ & $0.29^{\mathrm{b}} \pm 0.061$ & $<0.001$ \\
\hline $20: 4 n-6$ & $5.54^{\mathrm{a}} \pm 0.319$ & $1.32^{\mathrm{b}} \pm 0.377$ & $1.48^{\mathrm{b}} \pm 0.298$ & $<0.001$ \\
\hline $20: 5 n-3$ & $0.23^{\mathrm{a}} \pm 0.025$ & $0.06^{\mathrm{b}} \pm 0.033$ & $0.06^{\mathrm{b}} \pm 0.038$ & 0.002 \\
\hline $24: 0$ & $0.17 \pm 0.020$ & $0.15 \pm 0.023$ & $0.12 \pm 0.023$ & 0.327 \\
\hline $22: 4 n-6$ & $1.33^{\mathrm{a}} \pm 0.112$ & $0.16^{\mathrm{b}} \pm 0.133$ & $0.18^{\mathrm{b}} \pm 0.105$ & $<0.001$ \\
\hline $22: 5 n-6$ & $0.53 \pm 0.062$ & nd & nd & \\
\hline $22: 5 n-3$ & $0.84^{\mathrm{a}} \pm 0.057$ & $0.16^{\mathrm{b}} \pm 0.075$ & $0.23^{b} \pm 0.061$ & $<0.001$ \\
\hline $22: 6 n-3$ & $1.49^{\mathrm{a}} \pm 0.097$ & $0.21^{\mathrm{b}} \pm 0.115$ & $0.24^{\mathrm{b}} \pm 0.105$ & $<0.001$ \\
\hline \multicolumn{5}{|l|}{ Sums } \\
\hline BCFA & $3.79^{b} \pm 0.778$ & $1.36^{\mathrm{b}} \pm 0.921$ & $8.69^{a} \pm 0.728$ & $<0.001$ \\
\hline SFA & $290^{\mathrm{a}} \pm 19.0$ & $181^{\mathrm{b}} \pm 22.5$ & $304^{\mathrm{a}} \pm 17.8$ & 0.001 \\
\hline cis-MUFA & $399^{b} \pm 16.5$ & $342^{\mathrm{b}} \pm 19.5$ & $457^{\mathrm{a}} \pm 15.4$ & $<0.001$ \\
\hline trans-MUFA & $4.03^{\mathrm{C}} \pm 11.2$ & $150^{\mathrm{a}} \pm 13.3$ & $61.5^{\mathrm{b}} \pm 10.5$ & $<0.001$ \\
\hline n-6 PUFA & $312^{\mathrm{a}} \pm 10.6$ & $188^{\mathrm{b}} \pm 12.5$ & $153^{\mathrm{b}} \pm 9.9$ & $<0.001$ \\
\hline n-3 PUFA & $17.2^{\mathrm{a}} \pm 0.59$ & $9.67^{b} \pm 0.700$ & $8.25^{b} \pm 0.553$ & $<0.001$ \\
\hline PUFA & $332^{\mathrm{a}} \pm 11.3$ & $217^{\mathrm{b}} \pm 13.3$ & $175^{\mathrm{b}} \pm 10.5$ & $<0.001$ \\
\hline
\end{tabular}

1 - CONT: Control; HVF: hydrogenated vegetable fat; RUM: ruminant fat.

Averages on the same line with significant differences $(p<0.05)$ are indicated by different letters.

Table 6 - Fatty acid composition of the heart tissue of rats fed CONT, HVF and RUM diets (mg/g dry matter). 


\begin{tabular}{|c|c|c|c|c|}
\hline \multirow[t]{2}{*}{ Fatty acids } & \multicolumn{3}{|c|}{ Experimental Groups ${ }^{1}$} & \multirow[t]{2}{*}{$P$ value } \\
\hline & CONT & HVF & RUM & \\
\hline $14: 0$ & $0.22^{\mathrm{b}} \pm 0.118$ & $0.28^{\mathrm{b}} \pm 0.139$ & $1.11^{\mathrm{a}} \pm 0.118$ & $<0.001$ \\
\hline $\mathrm{i}-15: 0$ & nd & nd & $0.09 \pm 0.008$ & - \\
\hline $\mathrm{a}-15: 0$ & nd & nd & $0.10 \pm 0.011$ & - \\
\hline $14: 1-c 9$ & $0.01 \pm 0.005$ & $0.01 \pm 0.005$ & $0.01 \pm 0.005$ & 0.243 \\
\hline $15: 0$ & $0.07^{\mathrm{b}} \pm 0.024$ & $0.05^{\mathrm{b}} \pm 0.029$ & $0.28^{\mathrm{a}} \pm 0.024$ & $<0.001$ \\
\hline $\mathrm{i}-16: 0$ & $0.03^{\mathrm{b}} \pm 0.010$ & $0.01^{\mathrm{b}} \pm 0.012$ & $0.12^{\mathrm{a}} \pm 0.010$ & $<0.001$ \\
\hline $16: 0$ & $9.57^{\mathrm{b}} \pm 1.312$ & $9.87^{b} \pm 1.55$ & $16.6^{\mathrm{a}} \pm 1.31$ & 0.003 \\
\hline $16: 1-t$ & $0.03^{b} \pm 0.024$ & $0.25^{\mathrm{a}} \pm 0.029$ & $0.00^{\mathrm{b}} \pm 0.024$ & $<0.001$ \\
\hline i-1 $7: 0$ & $0.03^{\mathrm{b}} \pm 0.014$ & $0.02^{\mathrm{b}} \pm 0.016$ & $0.16^{\mathrm{a}} \pm 0.014$ & $<0.001$ \\
\hline $16: 1-c 7$ & $0.07^{\mathrm{b}} \pm 0.030$ & $0.09^{\mathrm{b}} \pm 0.036$ & $0.32^{\mathrm{a}} \pm 0.030$ & $<0.001$ \\
\hline $16: 1-c 9$ & $0.53 \pm 0.128$ & $0.16 \pm 0.152$ & $0.64 \pm 0.128$ & 0.076 \\
\hline $\mathrm{a}-17: 0$ & $0.02^{\mathrm{b}} \pm 0.021$ & $0.01^{\mathrm{b}} \pm 0.025$ & $0.26^{\mathrm{a}} \pm 0.021$ & $<0.001$ \\
\hline $17: 0$ & $0.25^{\mathrm{b}} \pm 0.046$ & $0.12^{\mathrm{b}} \pm 0.054$ & $0.64^{\mathrm{a}} \pm 0.046$ & $<0.001$ \\
\hline i-18:0 & $0.09 \pm 0.017$ & $0.09 \pm 0.020$ & $0.09 \pm 0.017$ & 0.990 \\
\hline $17: 1-c 9$ & $0.04^{\mathrm{b}} \pm 0.020$ & $0.08^{\mathrm{ab}} \pm 0.024$ & $0.16^{\mathrm{a}} \pm 0.020$ & 0.002 \\
\hline $18: 0$ & $16.8^{\mathrm{b}} \pm 1.09$ & $15.7^{\mathrm{b}} \pm 1.29$ & $27.7^{\mathrm{a}} \pm 1.09$ & $<0.001$ \\
\hline $18: 1-t 6 /-t 7 /-t 8$ & $0.15^{\mathrm{b}} \pm 0.120$ & $0.94^{\mathrm{a}} \pm 0.142$ & $0.22^{b} \pm 0.120$ & 0.001 \\
\hline $18: 1-t 9$ & $0.37^{\mathrm{b}} \pm 0.257$ & $2.52^{\mathrm{a}} \pm 0.304$ & $0.38^{\mathrm{b}} \pm 0.257$ & $<0.001$ \\
\hline $18: 1-t 10$ & $0.20^{\mathrm{b}} \pm 0.193$ & $1.37^{\mathrm{a}} \pm 0.229$ & $0.29^{b} \pm 0.193$ & 0.003 \\
\hline $18: 1-t 11$ & $0.41^{\mathrm{b}} \pm 0.276$ & $2.17^{\mathrm{a}} \pm 0.326$ & $2.44^{\mathrm{a}} \pm 0.264$ & $<0.001$ \\
\hline $18: 1-t 12$ & $0.31^{\mathrm{b}} \pm 0.179$ & $1.88^{\mathrm{a}} \pm 0.212$ & $0.32^{\mathrm{b}} \pm 0.179$ & $<0.001$ \\
\hline $18: 1-c 9$ & $7.47^{\mathrm{b}} \pm 2.972$ & $12.4^{\mathrm{b}} \pm 3.517$ & $29.7^{\mathrm{a}} \pm 2.972$ & $<0.001$ \\
\hline $18: 1-t 15$ & $0.09^{\mathrm{b}} \pm 0.070$ & $0.51^{\mathrm{a}} \pm 0.083$ & $0.17^{\mathrm{b}} \pm 0.070$ & 0.004 \\
\hline $18: 1-c 11$ & $2.27 \pm 0.110$ & $2.37 \pm 0.130$ & $2.11 \pm 0.110$ & 0.333 \\
\hline $18: 1-c 12$ & $0.23^{\mathrm{b}} \pm 0.133$ & $1.27^{\mathrm{a}} \pm 0.157$ & $0.11^{\mathrm{b}} \pm 0.133$ & $<0.001$ \\
\hline $18: 1-c 13$ & $0.05^{\mathrm{b}} \pm 0.015$ & $0.18^{\mathrm{a}} \pm 0.018$ & $0.03^{\mathrm{b}} \pm 0.015$ & $<0.001$ \\
\hline $18: 1-t 16 /-c 14$ & $0.03^{\mathrm{b}} \pm 0.014$ & $0.15^{\mathrm{a}} \pm 0.02$ & $0.17^{\mathrm{a}} \pm 0.014$ & $<0.001$ \\
\hline $18: 1-c 15$ & $0.01^{b} \pm 0.004$ & $0.05^{\mathrm{a}} \pm 0.004$ & $0.02^{\mathrm{b}} \pm 0.004$ & $<0.001$ \\
\hline $18: 2 n-6$ & $18.1 \pm 1.16$ & $19.0 \pm 1.37$ & $18.2 \pm 1.16$ & 0.859 \\
\hline $20: 0$ & $0.07^{\mathrm{b}} \pm 0.014$ & $0.10^{\mathrm{ab}} \pm 0.016$ & $0.12^{\mathrm{a}} \pm 0.014$ & 0.029 \\
\hline $18: 3 n-6$ & $0.02 \pm 0.003$ & $0.01 \pm 0.004$ & $0.02 \pm 0.003$ & 0.303 \\
\hline $18: 3 n-3 / 20: 1-c 11$ & $0.24^{\mathrm{b}} \pm 0.057$ & $0.33^{a b} \pm 0.068$ & $0.51^{\mathrm{a}} \pm 0.057$ & 0.014 \\
\hline
\end{tabular}




\begin{tabular}{lcccc}
$18: 2-c 9 t 11$ & $0.02^{\mathrm{b}} \pm 0.036$ & $0.06^{\mathrm{b}} \pm 0.043$ & $0.43^{\mathrm{a}} \pm 0.036$ & $<0.001$ \\
\hline $20: 2 \mathrm{n}-6$ & $0.14^{\mathrm{a}} \pm 0.010$ & $0.07^{\mathrm{b}} \pm 0.013$ & $0.09^{\mathrm{b}} \pm 0.011$ & 0.004 \\
\hline $20: 3 \mathrm{n}-9$ & $0.02^{\mathrm{b}} \pm 0.003$ & $0.01^{\mathrm{b}} \pm 0.004$ & $0.09^{\mathrm{a}} \pm 0.003$ & $<0.001$ \\
\hline $22: 0$ & $0.03^{\mathrm{b}} \pm 0.008$ & $0.07^{\mathrm{a}} \pm 0.009$ & $0.05^{\mathrm{ab}} \pm 0.008$ & 0.058 \\
\hline $20: 3 \mathrm{n}-6$ & $0.03^{\mathrm{b}} \pm 0.008$ & $0.07^{\mathrm{a}} \pm 0.009$ & $0.05^{\mathrm{ab}} \pm 0.008$ & 0.058 \\
\hline $20: 4 \mathrm{n}-6$ & $0.22^{\mathrm{b}} \pm 0.023$ & $0.32^{\mathrm{a}} \pm 0.027$ & $0.38^{\mathrm{a}} \pm 0.023$ & $<0.001$ \\
\hline $20: 5 \mathrm{n}-3$ & $15.9 \pm 0.87$ & $14.4 \pm 1.02$ & $15.3 \pm 0.87$ & 0.549 \\
\hline $24: 0$ & $0.03^{\mathrm{ab}} \pm 0.004$ & $0.02^{\mathrm{b}} \pm 0.005$ & $0.04^{\mathrm{a}} \pm 0.004$ & 0.024 \\
\hline $22: 4 \mathrm{n}-6$ & $0.69 \pm 0.035$ & $0.64 \pm 0.042$ & $0.64 \pm 0.035$ & 0.586 \\
\hline $22: 5 \mathrm{n}-6$ & $0.58 \pm 0.064$ & $0.41 \pm 0.076$ & $0.50 \pm 0.064$ & 0.270 \\
\hline $22: 5 \mathrm{n}-3$ & $1.01^{\mathrm{b}} \pm 0.146$ & $1.67^{\mathrm{a}} \pm 0.173$ & $1.74^{\mathrm{a}} \pm 0.146$ & 0.006 \\
\hline $22: 6 \mathrm{n}-3$ & $6.67^{\mathrm{b}} \pm 0.490$ & $9.08^{\mathrm{a}} \pm 0.580$ & $8.11^{\mathrm{ab}} \pm 0.490$ & 0.017
\end{tabular}

Sums

\begin{tabular}{lcccc} 
BCFA & $0.17^{\mathrm{b}} \pm 0.061$ & $0.13^{\mathrm{b}} \pm 0.072$ & $0.81^{\mathrm{a}} \pm 0.061$ & $<0.001$ \\
\hline SFA & $27.2^{\mathrm{b}} \pm 2.52$ & $26.4^{\mathrm{b}} \pm 2.98$ & $47.3^{\mathrm{a}} \pm 2.52$ & $<0.001$ \\
\hline cis-MUFA & $10.6^{\mathrm{b}} \pm 3.19$ & $15.5^{\mathrm{b}} \pm 3.78$ & $33.2^{\mathrm{a}} \pm 3.19$ & $<0.001$ \\
\hline trans-MUFA & $1.56^{\mathrm{b}} \pm 1.081$ & $9.63^{\mathrm{a}} \pm 1.279$ & $3.83^{\mathrm{b}} \pm 1.081$ & $<0.001$ \\
\hline $\mathrm{n}-6$ PUFA & $35.6 \pm 1.22$ & $34.9 \pm 1.44$ & $35.1 \pm 1.22$ & 0.915 \\
\hline $\mathrm{n}-3$ PUFA & $8.0^{\mathrm{b}} \pm 0.54$ & $11.1^{\mathrm{a}} \pm 0.64$ & $10.4^{\mathrm{a}} \pm 0.54$ & 0.003 \\
\hline PUFA & $43.6 \pm 1.43$ & $46.1 \pm 1.69$ & $46.0 \pm 1.43$ & 0.426 \\
\hline
\end{tabular}

1 - CONT: Control; HVF: hydrogenated vegetable fat; RUM: ruminant fat.

Averages on the same line with significant differences $(p<0.05)$ are indicated by different letters.

\section{Figures}


(A)

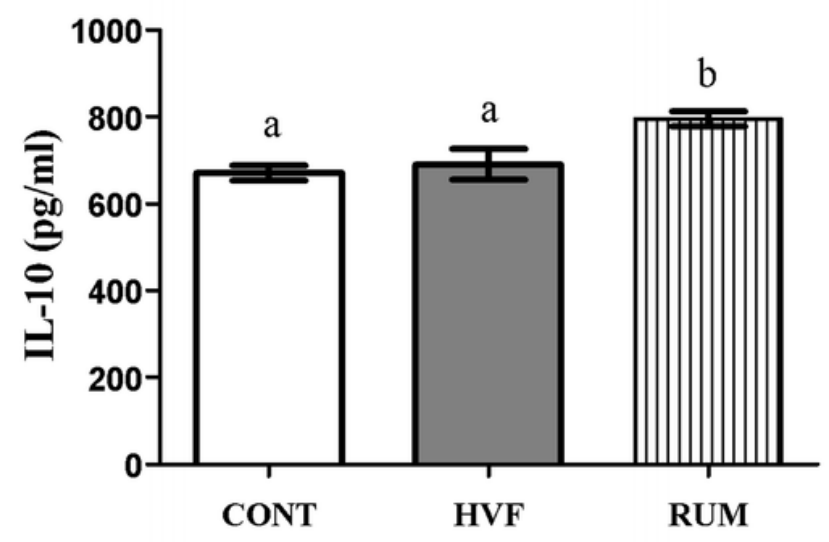

(B)

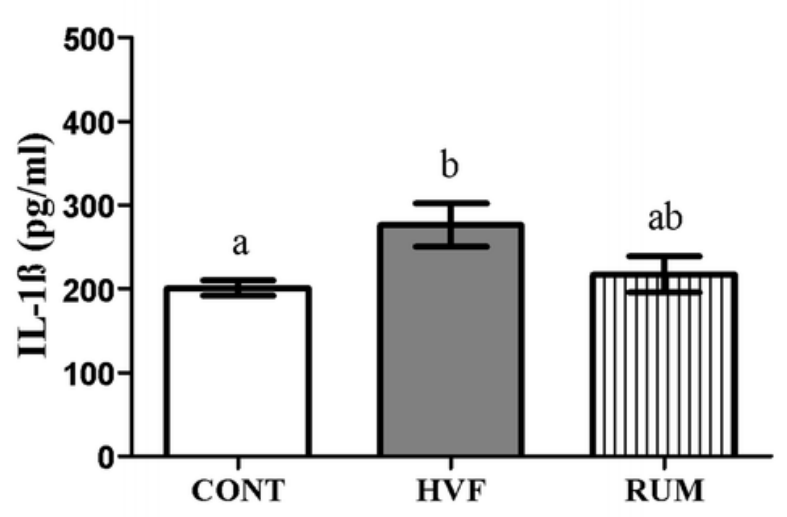

(C)

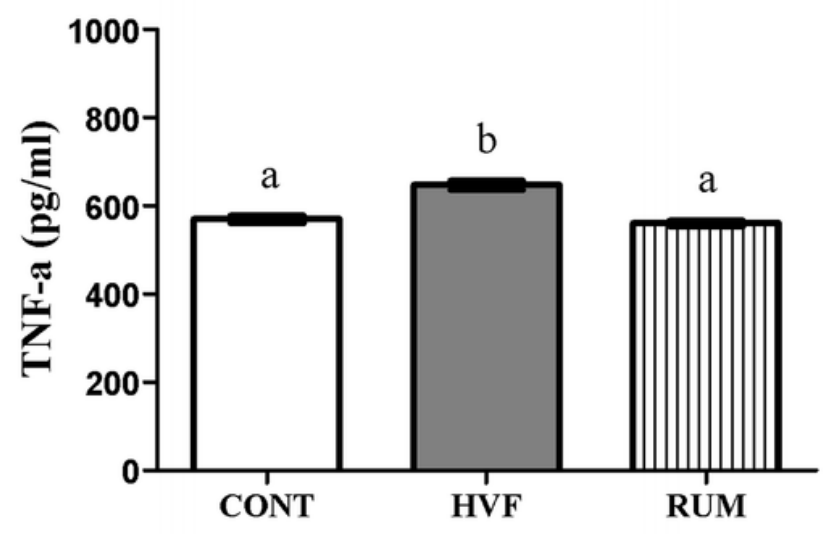

Figure 1

Concentration of serum cytokine of adult rats that were exposed to control diet (CONT) ( $n=9)$ or diets supplemented with hydrogenated vegetable fat $(H V F)(n=9)$ or ruminant fat (RUM) $(n=9)$. (A) Concentration of IL-10: Interleukin 10. (B) Concentration of IL-1ß: Interleukin 1B, (C) Concentration of TNF-a: Alpha Tumour Necrosis Factor. Values expressed as mean and standard deviation represented by vertical bars (One-way ANOVA, Tukey); Different letters at the top of the bars indicate significant differences between groups $(P<0.05)$. 
(A)

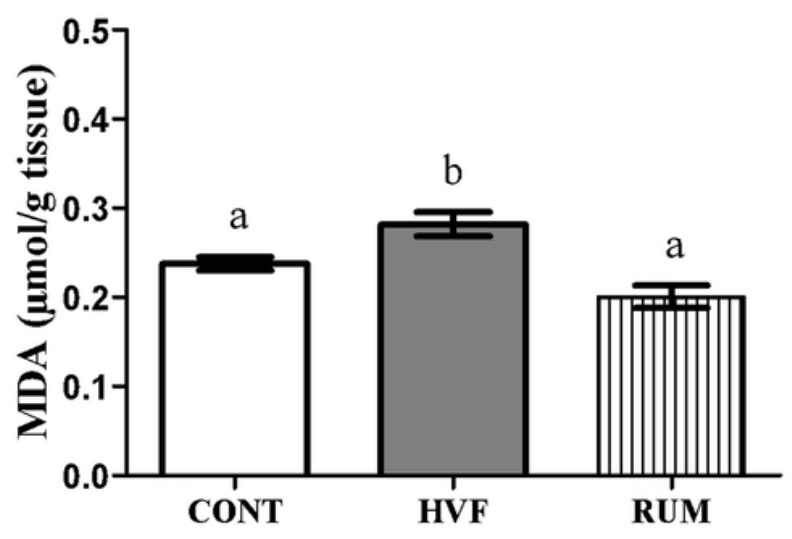

(B)

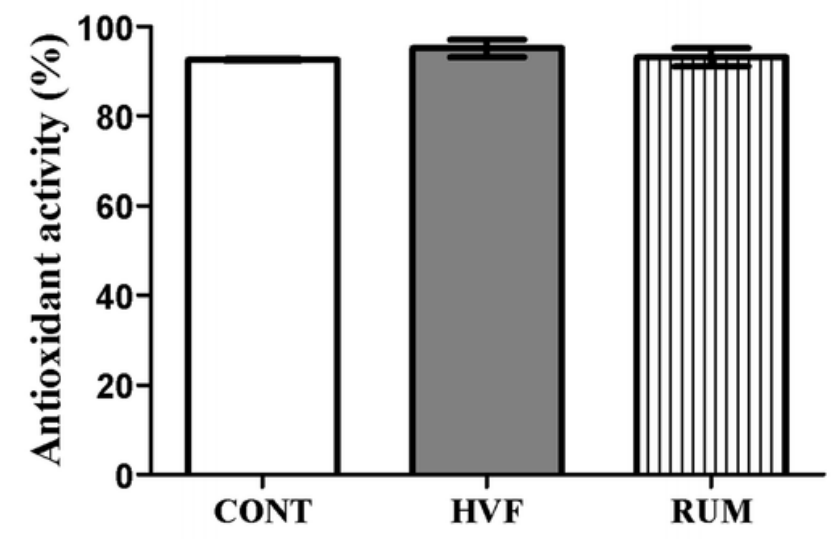

\section{Figure 2}

Concentration of malondialdehyde (MDA) (A) and antioxidant activity (B) of rat livers that were exposed to control diet (CONT) $(n=9)$ or diets supplemented with hydrogenated vegetable fat (HVF) $(n=9)$ or ruminant fat $(R \cup M)(n=9)$. Values expressed as mean and standard deviation represented by vertical bars (One-way ANOVA, Tukey); Different letters at the top of the bars indicate significant differences between groups $(P<0.05)$. 


\section{(A)}

\section{CONT}
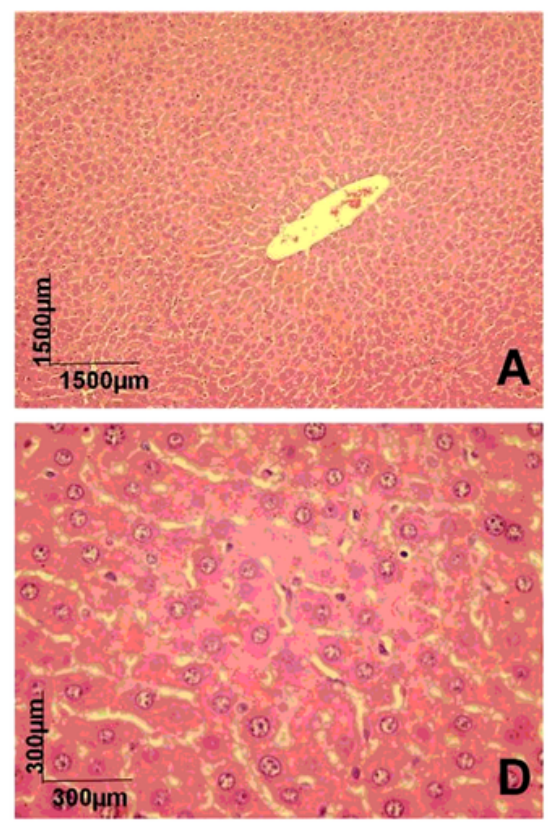

HVF
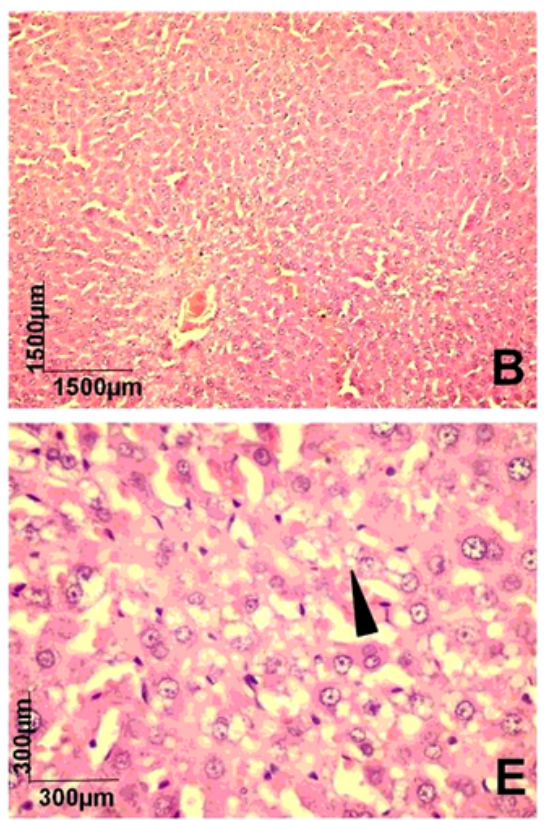

\section{RUM}

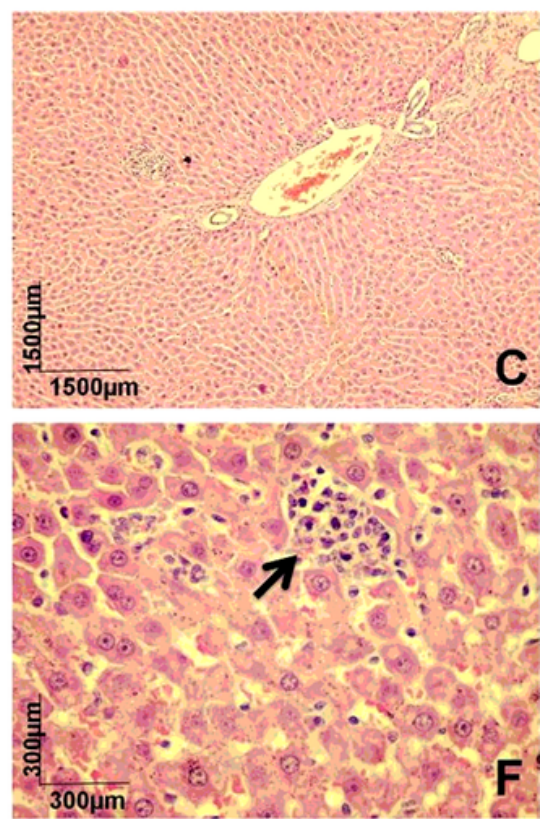

(B)

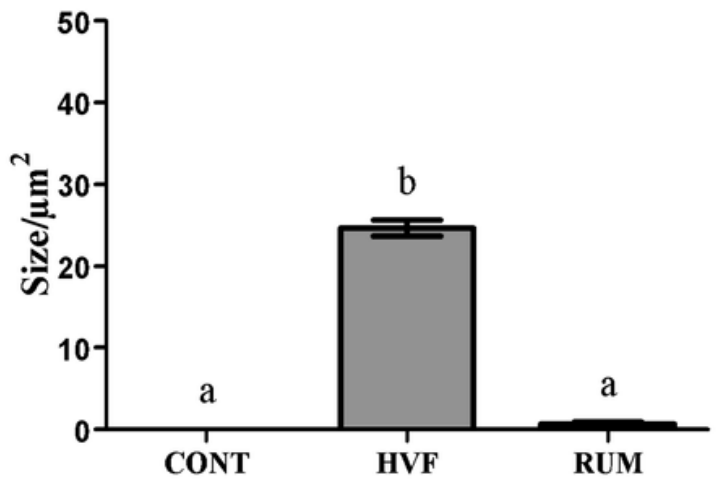

\section{Figure 3}

Liver histology (A) and histological morphometry of hepatic steatosis (B) of rat livers that were exposed to control diet (CONT) or diets supplemented with hydrogenated vegetable fat (HVF) or ruminant fat (RUM). Values expressed as mean and standard deviation represented by vertical bars (One-way ANOVA, Tukey); Different letters at the top of the bars indicate significant differences between groups $(P<0.0001) . \rightarrow$ Steatosis; $\boldsymbol{\Delta}$ Inflammation. 
(A)

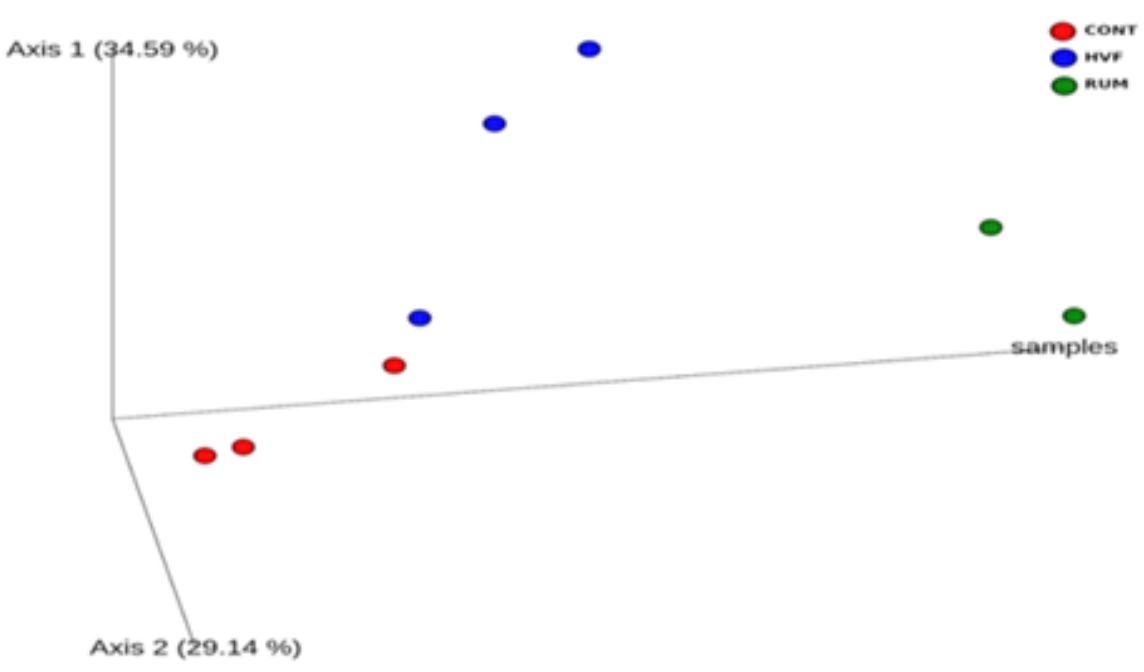

(B)

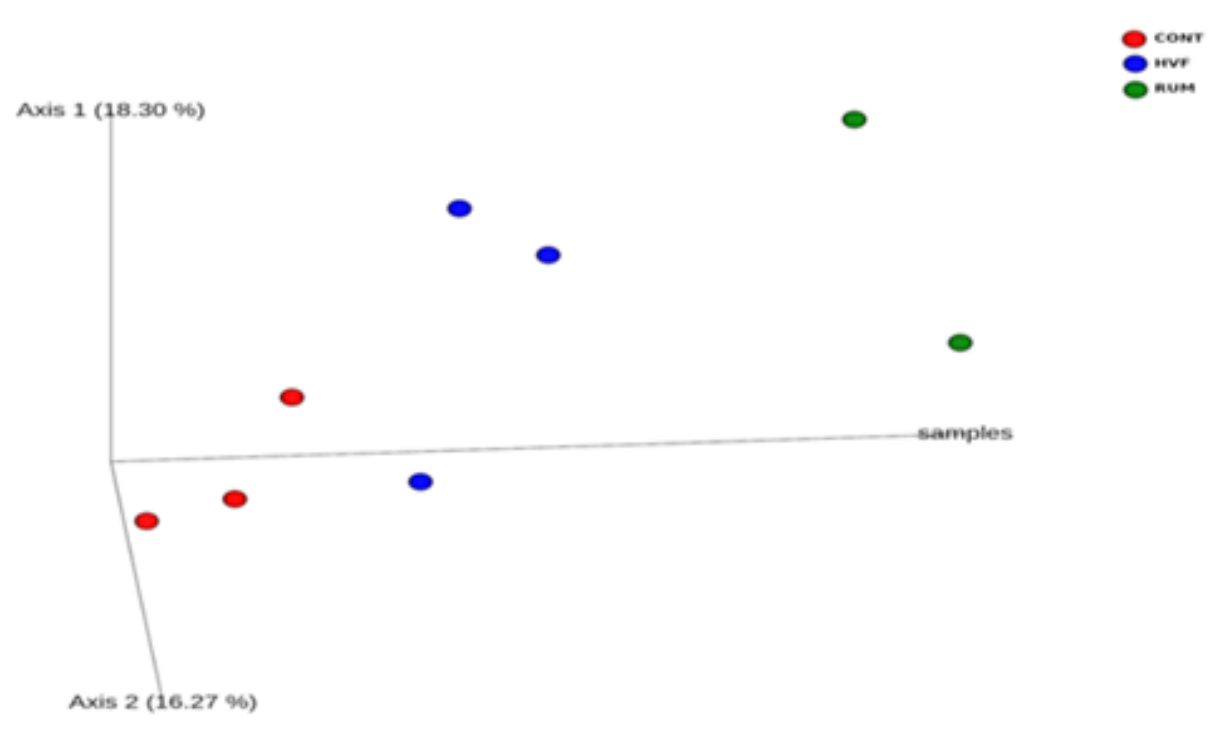

Figure 4

Principal coordinates analysis (PCoA) based on weighted (A) and unweighted-Unifrac (B) distance matrixes of gut microbiota composition of rats exposed to control diet (CONT) or diets supplemented with hydrogenated vegetable fat (HVF) or ruminant fat (RUM). 

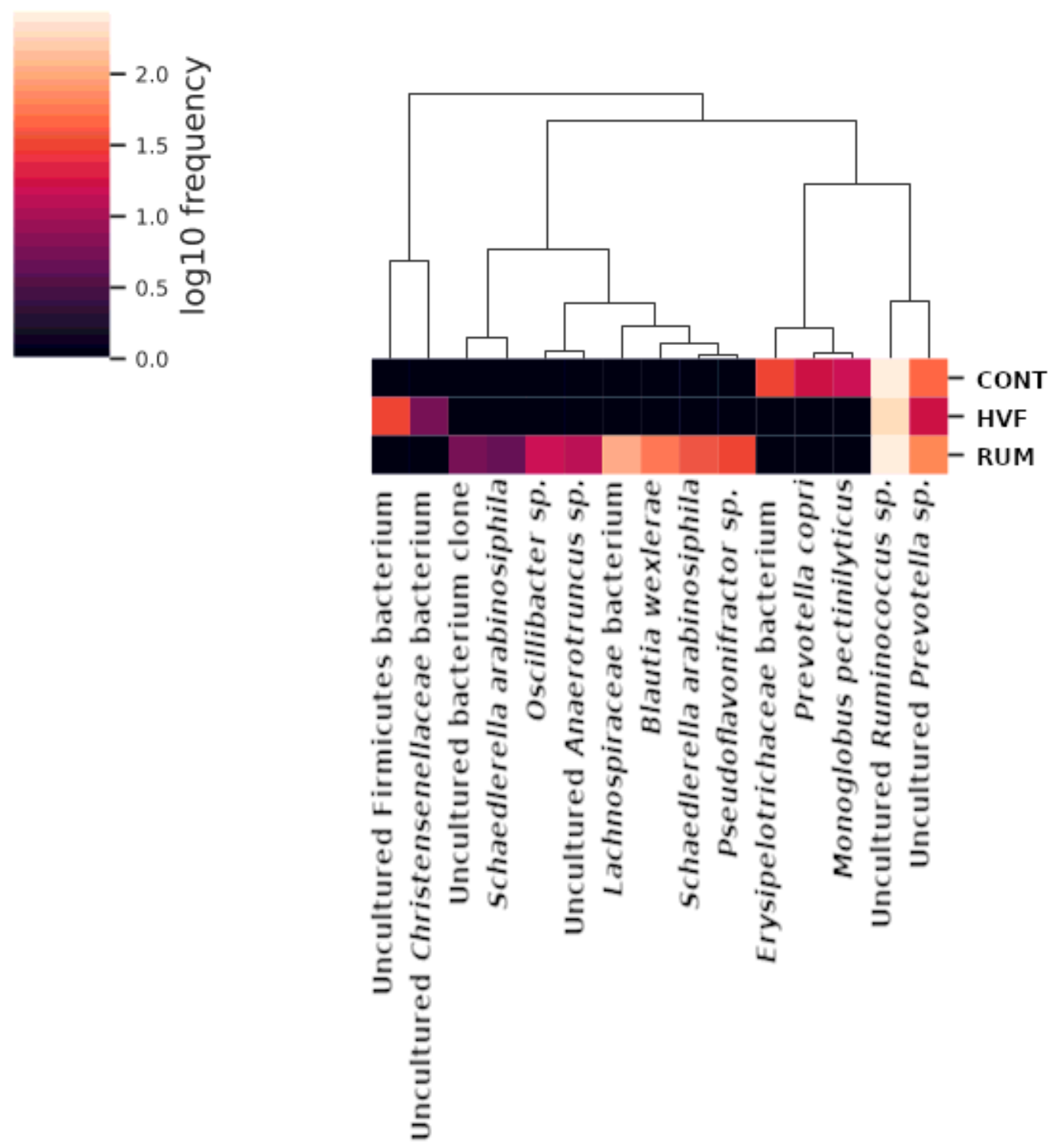

Figure 5

Principal coordinates analysis (PCOA) based on weighted (A) and unweighted-Unifrac (B) distance matrixes of gut microbiota composition of rats exposed to control diet (CONT) or diets supplemented with hydrogenated vegetable fat (HVF) or ruminant fat (RUM).

\section{Supplementary Files}

This is a list of supplementary files associated with this preprint. Click to download.

- Sumpplementaryfigues.pdf 